INTERNATIONAL

FOOD POLICY

RESEARCH

INSTITUTE

IFPRI

IFPRI Discussion Paper 01893

December 2019

\title{
Deepening Decentralization in Zambia \\ Political Economy Constraints and Opportunities for Reform
}

\author{
Danielle Resnick \\ Gilbert Siame \\ Peter Mulambia \\ Dorothy Ndhlovu \\ Beverly Shicilenge \\ Bhavna Sivasubramanian
}

Development Strategy and Governance Division 


\section{INTERNATIONAL FOOD POLICY RESEARCH INSTITUTE}

The International Food Policy Research Institute (IFPRI), established in 1975, provides research-based policy solutions to sustainably reduce poverty and end hunger and malnutrition. IFPRI's strategic research aims to foster a climate-resilient and sustainable food supply; promote healthy diets and nutrition for all; build inclusive and efficient markets, trade systems, and food industries; transform agricultural and rural economies; and strengthen institutions and governance. Gender is integrated in all the Institute's work. Partnerships, communications, capacity strengthening, and data and knowledge management are essential components to translate IFPRI's research from action to impact. The Institute's regional and country programs play a critical role in responding to demand for food policy research and in delivering holistic support for country-led development. IFPRI collaborates with partners around the world.

\section{AUTHORS}

Danielle Resnick (d.resnick@cgiar.org) is a Senior Research Fellow in the Development Strategy and Governance Division at the International Food Policy Research Institute (IFPRI), Washington, DC.

Gilbert Siame (siamegilbert@yahoo.co.uk) is a Lecturer in the Department of Geography and Environmental Studies at the University of Zambia and the Director of the Centre for Urban Research and Planning.

Peter Mulambia (petermulambia@yahoo.com) Dorothy Ndhlovu (ndhlovu.dorothy@yahoo.com), and Beverly Shicilenge (beverlyshicilenge@yahoo.com) are graduate students at the University of Zambia.

Bhavna Sivasubramanian (bhavnasiva20@gmail.com) is a Research Associate with J-PAL and formerly a Research Analyst in the Development Strategy and Governance Division at IFPRI.

\footnotetext{
Notices

${ }^{1}$ IFPRI Discussion Papers contain preliminary material and research results and are circulated in order to stimulate discussion and critical comment. They have not been subject to a formal external review via IFPRI's Publications Review Committee. Any opinions stated herein are those of the author(s) and are not necessarily representative of or endorsed by IFPRI.

${ }^{2}$ The boundaries and names shown and the designations used on the map(s) herein do not imply official endorsement or acceptance by the International Food Policy Research Institute (IFPRI) or its partners and contributors.

${ }^{3}$ Copyright remains with the authors. The authors are free to proceed, without further IFPRI permission, to publish this paper, or any revised version of it, in outlets such as journals, books, and other publications.
} 


\title{
Deepening Decentralization in Zambia: Political Economy Constraints and Opportunities for Reform*
}

\author{
Danielle Resnick $^{a}$, Gilbert Siame ${ }^{b}$, Peter Mulambia ${ }^{b}$, Dorothy Ndhlovu ${ }^{b}$, Beverly Shicilenge ${ }^{b}$ and \\ Bhavna Sivasubramanian $^{a}$ \\ ${ }^{a}$ International Food Policy Research Institute (IFPRI) \\ ${ }^{b}$ University of Zambia (UNZA)
}

\begin{abstract}
:
Since the early 2000s, decentralization has been espoused as a major policy goal of successive Zambian governments. With the passing of the 2019 Local Government Act, a greater understanding is needed of how decentralization has progressed thus far in Zambia and how political economy dynamics have constrained the process. As such, a survey was conducted with 153 bureaucrats across 16 councils in four Zambian provinces, complemented by interviews with elected ward councilors. Three key findings emerge. First, the organizational setting in which councils operate undermines the continuity of service provision. In particular, transfers of staff by the Local Government Service Commission (LGSC), partially driven by the growth in the number of councils in recent years, increases pressure on the wage bill of local authorities, creates uncertainty for civil servants, and undermines institutional memory. Second, the unwillingness to cede genuine autonomy to local councils by the Ministry of Local Government (MLG) repeatedly emerged. A perception of low levels of consultation with council bureaucrats and elected councilors, especially when statutory instruments are issued, reinforce that accountability remains upwards to the MLG rather than downwards to citizens. Third, within the councils, there is a mismatch in incentives between the bureaucrats and politicians that can undermine policy implementation; while the former respect authority and attention to procedures, the latter are focused on constituents' priorities and may bypass formal procedures to deliver to their voters. Based on interviews with market committees and solid waste companies, these dynamics have negative externalities on citizen perceptions and service provision in urban areas. As one of the few analyses conducted with local bureaucrats to assess their experiences with decentralization, the study aims to advance both policy and scholarship about the political economy dynamics surrounding efforts to strengthen subnational capabilities in developing countries.
\end{abstract}

Keywords: decentralization, local governance, political economy, public sector reform, service delivery, urbanization, Zambia

\footnotetext{
${ }^{*}$ The authors gratefully acknowledge funding from the International Growth Centre (IGC) - Zambia and the support offered by IGC staff, especially Twivwe Siwale, Dennis Chiwele, and Anand Rajaram, in engaging with Zambian policymakers. They also appreciate additional funding provided by the CGIAR research program on Policies, Institutions, and Markets (PIM). They thank the Decentralization Secretariat in Zambia for its enthusiasm for the project and the many stakeholders who offered input into the project during a December 2018 workshop hosted at the University of Zambia. They also thank the many bureaucrats, waste collectors, market chairpeople, and ward councilors who generously gave their time during the study. Ethical clearance was obtained from IFPRI's Institutional Review Board, application approval number DSGD-19-0311. Any opinions expressed are those of the authors and do not necessarily reflect the policies or opinions of IFPRI, IGC, PIM, or UNZA.
} 


\section{Acronyms}

CBD

CBE

CDF

DHSS

LCC

LGA

LGEF

LGSC

MLG

MMD

NAPSA

PF

R-NDP

SI

UNIP

UPND

WDC

ZULAWU
Central Business District

Community-Based Enterprise

Constituency Development Fund

Department of Housing and Social Services

Lusaka City Council

Local Government Act

Local Government Equalization Fund

Local Government Service Commission

Ministry of Local Government

Movement for Multiparty Democracy

National Pension Scheme Authority

Patriotic Front

Revised National Decentralization Policy

Statutory Instrument

United National Independence Party

United Party for National Development

Ward Development Committee

Zambia United Local Authority Workers' Union 


\section{Deepening Decentralization in Zambia: Political Economy Constraints and Opportunities for Reform}

\section{Introduction}

Since the early 2000s, decentralization has been espoused as a major policy goal of successive Zambian governments. In both the Fifth (2006-2010) and Sixth National Development Plans (20112015), deepening decentralization, especially through devolution, was a key policy goal (GRZ 2006; GRZ 2011). Similarly, the country's current Seventh National Development Plan (2017-2021), emphasizes that insufficient decentralization contributed to the country's large economic and social inequalities: "The contributing factors that have led to inequalities include the inability to effectively implement the Decentralization Policy to an extent that resources and decision-making have precluded people at lower levels from effectively participating in the planning and implementation processes" (GRZ 2017: 91). ${ }^{1}$

Yet, despite this longstanding rhetorical commitment to decentralization, the country's local authorities remain constrained in their capacity to deliver development goods and services to the communities that they serve. The aim of this paper, therefore, is to assess how decentralization has progressed thus far in Zambia in light of the 2019 Local Government Act and the government's aspirations to move towards devolved local government. In particular, the study focuses on the binding constraints that hinder deepening decentralization. Binding constraints refer to the primary bottlenecks from which most other inefficiencies flow (Hausmann et al. 2005). This study focuses specifically on political economy dynamics as an underlying binding constraint. To do so, a survey was implemented in March 2019 with 153 bureaucrats across 16 councils in four Zambian provinces. This was then complemented with interviews with elected ward councilors in those councils. To identify the performance of decentralized government at delivering key services in urban areas, additional interviews occurred with market committees in 20 city markets and with private waste collection companies. In September 2019, additional interviews occurred with key national policymakers relevant to the decentralization process, namely the Decentralization Secretariat and the Local Government Service Commission.

Three key findings emerge. First, the organizational setting in which councils operate undermines the continuity of service provision. In particular, transfers of staff by the Local Government Services Commission (LGSC), partially driven by the growth in the number of councils in recent years and an unusually high number of transfers during the 2017-2018 period, has increased pressure on the wage bill of local authorities. At best, the unpredictability of transfers creates a sense of uncertainty for a

\footnotetext{
${ }^{1}$ Inequality remains one of Zambia's most pressing concerns, especially as the country's Gini coefficient increased from 0.65 to 0.69 between 2010 and 2015 based on household expenditure measures (CSO 2016). A Gini coefficient ranges from 0 to 1 with 0 indicating complete equality and 1 meaning complete inequality.
} 
bureaucratic cadre that is otherwise well-educated and committed to improving local government. At worst, such transfers can be perceived -rightly or wrongly — as politically motivated since the LGSC is appointed by the president and local politicians seem to have power to influence the transfer of council staff. Second, the unwillingness to cede actual autonomy to local councils by the Ministry of Local Government (MLG) repeatedly emerged. A perception of low levels of consultation with council bureaucrats and elected councilors, especially when statutory instruments are issued, reinforce that accountability remains upwards to the MLG. Even the composition of ward development committees for community consultation is dictated by the MLG and expected to be replicated in every council. Third, within the councils, there is a mismatch in incentives between the bureaucrats and politicians that can undermine policy implementation; while the former respect authority and attention to procedures, the latter are focused on constituents' priorities and may bypass formal procedures to deliver to their voters.

These constraints manifest in the provision of certain services in the local councils, particularly with respect to market/street trade management and solid waste collection. These two services legally are exclusive mandates of the local authorities according to the 2016 Constitution and the Markets and Bus Station Act of 2007 (see GRZ 2016). In addition, they are critical areas of focus to improve the livelihoods of the poor, who often depend heavily on markets for employment and who often lack sufficient household waste collection. The two services are also interlinked since inadequate waste collection often increases food safety and public health hazards, particularly cholera, that can emerge in informal markets.

The contributions of the research are twofold. First, a number of studies lament the challenges of deepening decentralization in Zambia (e.g. Chulu 2014; Hampwaye 2008, LGAZ 2014). However, to our knowledge, this is the first survey conducted with bureaucrats in Zambia to assess the extent of these challenges across councils and then look at the implications of stalled decentralization for service provision. Secondly, low state capabilities constitute the most significant growth policy challenge faced by developing countries, often resulting in the inability of even well-intentioned policies to be implemented on the ground (Andrews 2017). Subnational capabilities typically are even weaker due to insufficient resources, lack of technical expertise, and competition from alternative sources of legitimacy, such as traditional authorities. In urban areas, this is problematic because strong local governments are essential partners for managing rapid population growth and urbanization. In rural areas, capable local authorities could assist in providing the enabling environment for nascent industries to develop and improve access to markets. As such, empirically analyzing to what extent political economy dynamics constitute binding constraints to decentralization, and determining how they may vary spatially and across sectors, is a critical first step towards building sub-national state capabilities and addressing growthconstraining inequalities. 
The next section briefly reviews the aims of decentralization and political economy aspects that can undermine its potential by looking at areas of contestation and alignment between the central government, councils, local politicians, service providers, and citizens. Then, Zambia's history with decentralization and more recent initiatives are discussed. This is followed by a description of the data used for this paper and some summary statistics of the bureaucrat survey sample. Subsequently, how these political dynamics unfurl are discussed. This includes a reluctance to relinquish power to local government by national ministries, the tussle by local governments for greater autonomy, including over human resource management, and the incentive clash between bureaucrats and politicians. In turn, the implications for market and waste management are analyzed. The final section concludes and offers policy recommendations.

\section{Promise and Pitfalls of Decentralization}

There are various ways in which decentralization can manifest. Delegation is effectively the most limited, which involves contracting a central government function to another public or private entity. Deconcentration occurs when local units are outposts of central government ministries, thereby carrying out the roles and functions assigned to them by their national government. This structure results in local governments being accountable upwards to their line ministry. Devolution is the most comprehensive form of decentralization whereby elected local governments are given autonomy in service delivery areas as well as control over human resources, budgeting, and financial management. This transfer of functions and resources from the central to local government is legally-backed and therefore cannot be revoked. In this form, the anticipated improvements in local service delivery are complemented by increased downwards accountability to citizens, thereby enabling decentralization to also have an impact on good governance (Connerly et al. 2010; Faguet 2014; Smoke 2015).

Theoretically, decentralization can improve service provision by ensuring that government is closer to the people and therefore more aware of local needs and preferences. At the local level, citizens can be more demanding of the goods and services they receive due to their better oversight abilities (Oates 1985). In turn, they may feel more empowered to participate in decision-making and communicate their demands at that level than through national authorities, who may be too distant or anonymous for them (Brinkerhoff and Azfar 2010). Policymakers located closer to the citizens they serve can also more effectively learn about the preferences of those communities, which are believed to be more homogeneous than at the national level (Wallace and Oates 1998). Local governments can therefore compete by pursuing "preference matching," or tailoring the mix of goods and services they provide according to those preferences (Lederman et al. 2005; Oates 1972; Tiebout 1956). Under devolution, 
citizens can use their votes to either sanction or reward local politicians for providing the goods and services that best match their preferences.

However, many studies have shown that decentralization is always inherently a political process (e.g. Eaton et al. 2011; Falletti 2012; Gibson 2013). Despite avowedly lofty goals, central governments typically prefer to retain power and have an implicit disincentive to cede authority, relevance, and resources to subnational entities. For example, national governments may interfere in constitutionallymandated functions of local governments, or purposely withhold intergovernmental transfers, resulting in muddled accountability and insufficient resources (see Eaton et al. 2011). This can be particularly pronounced with devolution since sectoral ministries do not want to lose part of their mandates and privleges. In addition, in Westminster governance systems that are prevalent in anglophone Africa, ministries are led by MPs who are equally concerned about re-election prospects. More broadly, national ministries are working on behalf of the central government and want citizens to attribute good performance to their actions. These disincentives are exacerbated by partisan concerns as central governments fear that opposition parties may use control of local government to build subnational strongholds, or to foment ethnic nationalism (Estache et al 2016; Weingast 2014). In Africa, these challenges are most pronounced in urban areas, which tend to be more politically contested (Resnick 2014). In other words, the degree of partisan congruence between the central and local levels can serve as an intervening variable affecting the preference of national ministries to cede power.

Service providers, such as waste collectors, utility corporations, and construction companies, play a critical role in this dynamic since their actions directly determine the quality and quantity of goods and services that are available to citizens. They typically need to interact closely with bureaucrats in order to obtain procurement contracts, permits, and operating licenses. While their primary interest may be in recovering costs and potentially even making a profit, politicians will be concerned about whether the availability and quality of such services will be attributable by citizens to them and be rewarded at the voting booth (Batley and Mcloughlin 2015). This can lead to a notable disconnect between bureaucrats, who provide the enabling environment for service providers to operate, and politicians, who are ultimately accountable for their delivery.

Indeed, within local governments, there can be a broader incentive problem between bureaucrats and elected local politicians. On the one hand, local politicians have an incentive to provide interference and oversight to ensure bureaucrats perform according to their, and thereby citizens', preferences (Ellermann 2005). If bureaucrats are given too much discretion, or autonomy, they may abuse this to implement policies according to their own private goals and undermine policy effectiveness (Brehm and Gates 1999). Since politicians are elected while bureaucrats are not, the latter cannot be held accountable for unpopular policies, thereby justifying political oversight of bureaucrats' actions. 
On the other hand, bureaucrats need autonomy to perform the functions that were delegated to them. Political interference in bureaucratic autonomy can cause public expenditures to be targeted to narrow constituencies rather than to the broader community (Keefer and Khamani 2009) or result in local politicians using state resources for private gain (Ferraz and Finan 2011). In Pakistan, Callen et al. (2018) find that politicians prevent bureaucrats from sanctioning under-performing health workers when the latter are key political supporters and can mobilize votes on the politicians' behalf. Rogger (2018) observes that in Nigeria, membership on a legislative sectoral committee bestows politicians with a degree of power over bureaucrats in that sector. He finds that politicians' interference in small-scale capital projects forces bureaucrats to procure materials and labor from particular suppliers favored by those politicians.

The broader institutional setting in which local bureaucrats operate can condition which of these two trajectories is more pronounced. Bureaucratic capabilities are found to be higher when agents can operate in an environment of experimentation, novelty, and feedback loops (Andrews et al. 2013; Pires 2011). This typically occurs more often where bureaucrats have higher levels of autonomy (Fukuyama 2013). By contrast, bureaucrats can be demoralized in organizational settings that stymie flexibility or devalue hard work (Grindle 1997; Tummers and Bekkers 2014). Employment transfers are one institutional mechanism that can affect these dynamics. Such transfers have several important benefits, including creating a unified civil service culture and ensuring sufficient human resources in more economically deprived geographic regions. Yet, if such systems of transfers are viewed as politically motivated, dysfunctional, or opaque, these benefits are undermined. For example, bureaucrats who can be transferred if they oppose interference by politicians are less likely to speak up about corruption if they care about career advancement (Brierley forthcoming). In addition, unpredictable rotations can discourage innovation and experimentation because there is no certainty that the investment in time and energy will ultimately pay-off.

In sum, the implementation of decentralization requires grappling with political economy challenges in multiple domains, as shown in Figure 1. These include the potential clash between national and local governments as the former aims to retain power and relevance in key policy domains while the latter seeks greater autonomy, especially when devolution has been legally implemented. In addition, there are often mismatched interests between bureaucrats, who largely are concerned with job security and career fulfillment, and politicians, who are interested in delivering for their constituencies and obtaining re-election. In other words, the aspirations of political leadership are not always aligned with bureaucrats' job orientation and interests. Service providers play a critical role in these dynamics since their investments and interventions depend on bureaucratic support but their success (or failure) at 
meeting citizens' development needs has the greatest impact on politicians' career trajectories. All of these dynamics are relevant to understanding Zambia's fitful progress towards greater devolution.

\section{Figure 1: Political Economy Dynamics of Decentralization}

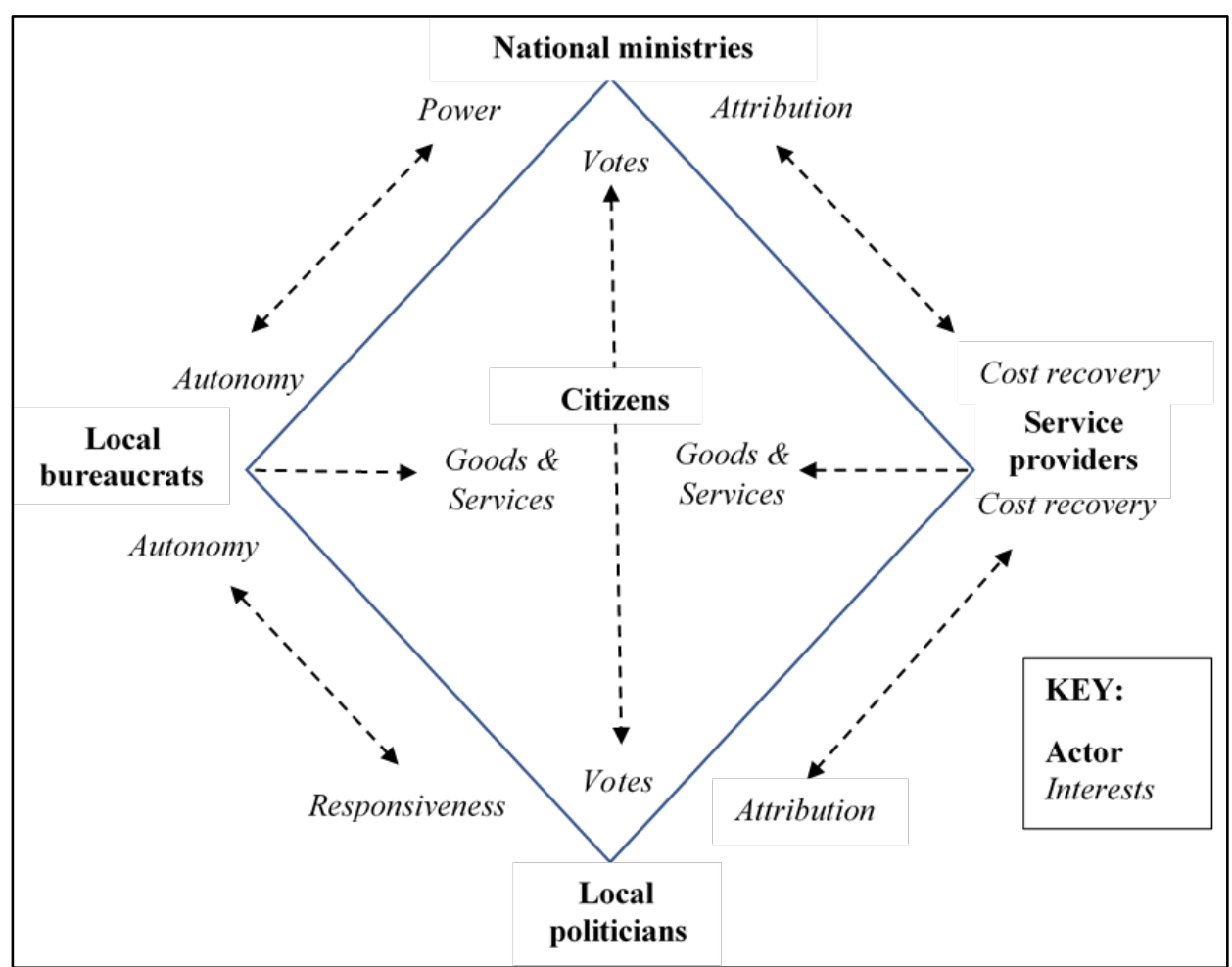

Source: Authors' compilation

\section{Background on decentralization in Zambia}

Zambia has had nearly forty years of experimentation with local government. In 1980, the United National Independence Party (UNIP) introduced the Local Administration Act that created an integrated local government structure, known as the district council, in the country's then 55 districts. Yet, in practice, the new structure became a way for the ruling party to entrench its power at the local level with council staff recruited from party members and resources utilized for party purposes (Tordoff and Young 1994).

When Zambia transitioned from a one-party state to a multi-party democracy in 1991, the newly elected Movement for Multiparty Democracy (MMD) pledged to pursue a more genuine decentralization process. As part of its Public Sector Reform Program with international donors, the MMD committed to deconcentrate functions to the provinces and devolve key functions to the local councils as their management capacities improved (Tordoff and Young 1994). As part of this effort, it introduced the 1991 
Local Government Act (LGA). ${ }^{2}$ This stipulated that mayors in city and municipal councils and chairmen/women in district councils would be elected by the councilors. In addition, section 61 of the Act stipulated that 63 functions would be transferred to the councils (GRZ 1991). Although a Local Government Services Commission (LGSC) originally was established to help with human resource and staffing decisions, this was abolished in 1995 because it gave the MLG minister undue influence in appointing the commissioners and determining the scope of their functions (Mwasile 2014). Instead, the councils were given the power to hire and fire staff.

Yet, the progress of delivering local services was disappointing, leading to the adoption of the 2002 Decentralization Policy, which was launched in 2004 and led to the establishment of the Decentralization Secretariat. This policy highlighted that the councils varied immensely in their capacities and promised reforms to enhance transparency and predictability in decision making at the local level, with matching resources to allow councils to carry out their functions (GRZ 2002). A Decentralization Implementation Plan was launched in December 2009 (GRZ 2009). In 2010, with the Local Government (Amendment) Act no. 6, the LGSC was re-established after complaints by council bureaucrats that elected politicians were abusing their positions through their control over staffing decisions (Mwasile 2014). In addition, councils struggled to recruit, train, and pay the salaries and other employment benefits of their staff (GRZ 2013), and wealthier councils were able to attract better qualified and experienced staff. ${ }^{3}$ The LGSC consists of five members who are appointed by the president for a three- to five-year term that is renewable once (GRZ 2010). The current commission was appointed in 2016 after the election of President Lungu.

In 2013, a new government under the Patriotic Front (PF) announced a Revised National Decentralization Policy (R-NDP) that, like previous decentralization policies, aimed to pursue a devolved form of governance through democratically elected local councils. The R-NDP recognized that decentralization in Zambia thus far has manifested as deconcentration whereby decision making and resources remained at the central government level and local governments were accountable upwards to the central government rather than downwards to citizens (GRZ2014c).The two overarching goals of the R-NDP were the following: 1) to have a fully autonomous local government with decision making authority on development priorities, collection and utilization of revenue as well as on its human resource and 2) to have an intergovernmental fiscal arrangement that recognizes local government as a primary service provider and contributes to improving its fiscal space to deliver on its mandate (GRZ 2014c).

In late 2014, the government released Circular No. 10, which provided guidelines on the implementation of the R-NDP over the 2015-2017 period (GRZ 2017a). It also formally announced the

\footnotetext{
2 This is often referred to as Local Government Act Cap 281.

${ }^{3}$ Interview with the LGSC.
} 
commencement of the devolution process and stipulated the creation of Ward Development Committees to facilitate citizen participation. In the same year, the Local Government Amendment Bill stated that the Local Government Equalization Fund (LGEF) would help fund the delivery of services within councils and will be comprised of no less than 5 percent of the total amount of income taxes collected in a particular fiscal year (GRZ 2014a). ${ }^{4}$ As seen in Figure 2 below, the amount allocated to the LGEF has marginally increased each year in nominal and real terms until 2019, when inflation became more pronounced. The MLG has expressed concerns that urban councils should no longer be using the LGEF since they have adequate means to raise their own money and that instead, it should be targeted to smaller councils in rural areas (Zande 2019), which disproportionately comprise the large number of new councils that have been created in recent years. This harkens back to the early 1990s when the Minister of Finance made a similar argument that city councils should be self-sufficient and stop receiving central government support (Tordoff and Young 1994). These arguments ignore, however, that urban councils face disproportionately larger service delivery challenges as well as larger staff sizes whose salaries need to be covered.

\footnotetext{
${ }^{4}$ Councils can receive three types of transfers from central government: 1) Constituency Development Fund for capital expenses, 2) Equalization fund to support council operations but with the stipulation that 20 percent goes towards capital expenditure, and 3) grants (IMF 2019).
} 
Figure 2: The Local Government Equalization Fund over Time in Zambian Kwacha

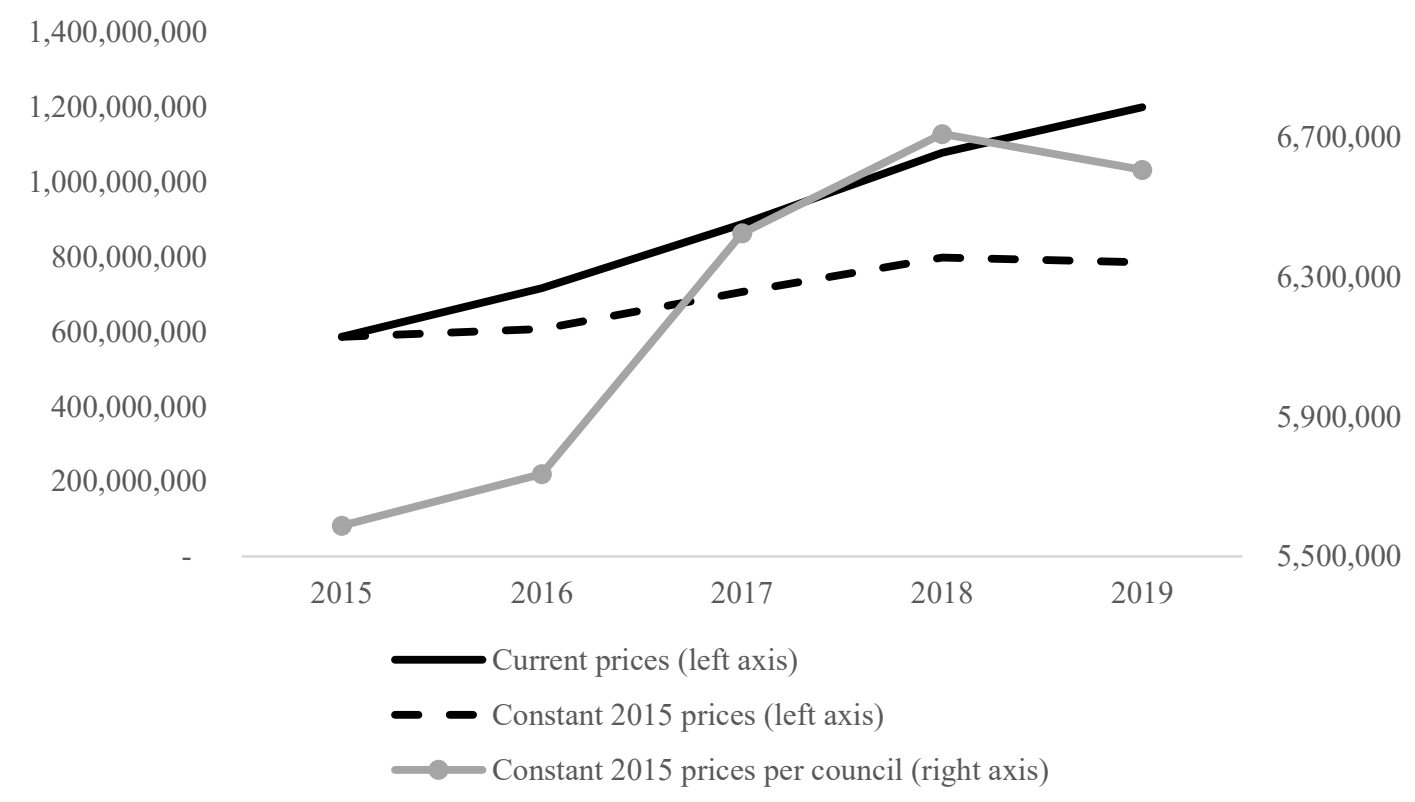

Sources: Data on the LGEF come from the annual Budget Speeches delivery by the Minister of Finance to Parliament and available at: http://www.mof.gov.zm/budget/. The conversion to 2015 constant prices was calculated with data on the consumer price index from the World Bank's World Development Indicators database and from Moody's Analytics.

According to the 2014 National Planning and Budgeting Policy, the local authorities are also expected to draft 10-year Integrated District Development Plans that will be aggregated into provincial plans and submitted to the Ministry of Finance (GRZ 2014b). The organizational structures of the district, municipal, and city councils were also revised to be more adept at performing the functions under their mandates (GRZ 2014d). These initiatives have been complemented by placing the Decentralization Secretariat within the Cabinet and, as stipulated in the 2016 Constitution, enabling mayors to be directly elected by citizens rather than by fellow councilors (GRZ 2016). At the sub-district level, Ward Development Committees (WDCs) were to be established in order to enhance community participation in decision making (GRZ 2014c).

At the same time, the government increased the number of local authorities across the country. According to the Provincial and District Boundaries Act Cap 286 of the Laws of Zambia, the President is empowered to declare new provinces and districts. Under the PF, the number of officially recognized councils grew from 74 in 2011 to 119 by mid-2018. This includes 5 city councils, 14 municipal councils, and 100 town councils. The oft-repeated rationale for creating new councils typically is to ensure development and services are brought closer to the people (Lusaka Times 2018a; Lusaka Times 2018b). 
City councils need to have more than 100,000 people with high population density, and they typically contain a relatively wide diversity of economic activities. Municipal councils are in peri- and suburban areas, with at least 30,000 people, while town councils are found in relatively rural regions where population is lower and there is a greater prevalence of agricultural activity (GRZ 2017b). Regardless of this variation in size, the mandates and authority vis-à-vis residents and the national government remain the same across all councils. Each council has both a political and an administrative wing. In the political wing, councilors are elected directly by constituents based on the first-past-the-post system as representatives of the residents. Since 2016, citizens have also directly elected the political head, known as the Mayor in city and municipal councils and the Council Chairperson in district councils. The Town Clerk in city and municipal councils, and the Council Secretary in district councils, serve as the executive head of the council. These officials in the administrative wing are hired by the LGSC.

In terms of staffing, city councils are proposed to employ 6,151 civil servants, with the exception of Lusaka City Council, which is to employ 6,958 staff. Municipal councils can have 2,675 posts while district councils are intended to staff 2,089 officials. Salary structures also vary across councils, even including differential salary grades for some equivalent posts across councils. For example, a Town Clerk at the municipal council level is compensated less than a Town Clerk operating in a city council (GRZ 2014d).

Despite the longstanding enthusiasm for decentralization in general and devolution in particular, a variety of government oversight actors, including the Parliamentary Committee on Local Government, the Decentralization Secretariat, and the Auditor General have reported continued challenges with implementation (GRZ 2017, 2018a, 2018b). These range from the lack of financial resources for goods and services, the halting of the WDC formation process, and the perceived arbitrary nature of transfers under the LGSC. Yet, there has been a dearth of analysis drawing on comparative data across councils to determine how decentralization is progressing, the root challenges to deepening decentralization, and the impacts of the current status of local government on service provision.

\section{Data Collection}

To gain a better perspective on decentralization, a survey was conducted in March 2019 with staff in 16 councils across 4 provinces: Central, Copperbelt, Lusaka, and Southern. ${ }^{5}$ Although these are some of Zambia's most centrally located provinces, Table 1 highlights that they span a wide variety of economic and political circumstances. Specifically, 7 of the sampled councils were under the United Party

\footnotetext{
${ }^{5}$ Bureaucrats were promised anonymity so specific citations to their responses are provided in the text in a way that provides the most specificity without identifying the respondent. Ward councilors, market chairpeople, and waste collectors were asked if they felt comfortable being identified by their position, affiliation, and location but not by name; only those who replied "yes" are identified with their responses in the text.
} 
for National Development (UPND) mayoral leadership and 9 councils were headed by a Patriotic Front (PF) mayor. Except for Chilanga, the affiliation of the mayor in all councils aligns with the affiliation of the majority of the elected ward councilors. In addition to four city councils, Ndola, Kitwe, Lusaka, and Livingstone, the sample also encompassed municipal and town councils as well. Six councils in the sample are new since 2011. Not surprisingly, the town councils typically have higher poverty rates and lower budgets. In general, the council budgets span a large range, from K10 million in Pemba to K 390 million in Lusaka. ${ }^{6}$

${ }^{6}$ As of December 2019, 1 USD = 14.5 Zambian kwacha. 
Table 1: Overview of Sampled Councils

\begin{tabular}{|c|c|c|c|c|c|c|c|c|c|}
\hline Province & Council & $\begin{array}{l}\text { Council } \\
\text { type }\end{array}$ & $\begin{array}{l}\text { Poverty } \\
\text { Rate, } \\
\mathbf{2 0 1 5} \\
(\%)\end{array}$ & $\begin{array}{l}\text { Mayor's } \\
\text { party } \\
\text { affiliation, } \\
2018\end{array}$ & $\begin{array}{l}\text { Newly } \\
\text { created } \\
\text { council } \\
\text { since } \\
2011 ?\end{array}$ & $\begin{array}{l}\text { Budgeted } \\
\text { expenditures } \\
\text { (Zambian } \\
\text { Kwacha, } \\
\text { 2018) }\end{array}$ & $\begin{array}{l}\text { Share of } \\
\text { central } \\
\text { government } \\
\text { transfers in } \\
\text { budget, (\%, } \\
\text { 2018) }\end{array}$ & $\begin{array}{l}\text { Share of } \\
\text { expenditures } \\
\text { on personnel } \\
\text { emoluments, } \\
(\%, 2018 \\
\text { estimates })\end{array}$ & $\begin{array}{l}\text { Share of } \\
\text { expenditures } \\
\text { on goods } \\
\text { and services } \\
\text { (\%, 2018 } \\
\text { estimates) }\end{array}$ \\
\hline Central & Chibombo & Town & 73 & UPND & No & $22,379,400$ & $50.0^{*}$ & 43.8 & 42.3 \\
\hline Central & Chisamba & Town & 71 & UPND & Yes & --- & --- & --- & --- \\
\hline Central & Kabwe & Municipal & 33 & $\mathrm{PF}$ & No & $58,051,685$ & $50.0^{*}$ & 38.3 & 42.4 \\
\hline Central & Ngabwe & Town & 81 & $\mathrm{PF}$ & Yes & $11,767,928^{*}$ & $93.0^{*}$ & $60.0 *$ & $20.0^{*}$ \\
\hline Copperbelt & Chililabombwe & Municipal & 30 & $\mathrm{PF}$ & No & $50,997,990$ & $30.0^{*}$ & 41.0 & 36.1 \\
\hline Copperbelt & Kitwe & City & 29 & $\mathrm{PF}$ & No & $157,925,241$ & $20.0^{*}$ & 37.2 & 51.6 \\
\hline Copperbelt & Luanshya & Municipal & 33 & $\mathrm{PF}$ & No & $64,796,902$ & --- & 41.9 & 43.5 \\
\hline Copperbelt & Ndola & City & 31 & $\mathrm{PF}$ & No & $179,652,734$ & $30.0 *$ & 31.3 & 43.3 \\
\hline Lusaka & Chilanga & Town & 36 & $\mathrm{PF}$ & Yes & $15,023,985$ & 36.3 & 33.5 & 54.8 \\
\hline Lusaka & Chirundu & Town & 47 & UPND & Yes & $18,453,363$ & 48.6 & 30.6 & 53.5 \\
\hline Lusaka & Chongwe & Municipal & 61 & $\mathrm{PF}$ & No & $21,355,521$ & $50.0^{*}$ & 50.0 & 43.1 \\
\hline Lusaka & Lusaka & City & 18 & $\mathrm{PF}$ & No & $390,117,589$ & 14.3 & 42.6 & 39.5 \\
\hline Southern & Choma & Municipal & 72 & UPND & No & $27,429,340$ & 52.9 & 44.3 & 41.3 \\
\hline Southern & Livingstone & City & 28 & UPND & No & $79,557,409$ & 20.3 & 49.1 & 35.7 \\
\hline Southern & Pemba & Town & 82 & UPND & Yes & $10,797,982$ & 66.0 & 50.0 & 41.8 \\
\hline Southern & Zimba & Town & 73 & UPND & Yes & $13,783,144$ & 62.6 & 44.8 & 44.6 \\
\hline
\end{tabular}

Source: Authors' compilation from the IFPRI-UNZA Zambia Local Bureaucrats survey data, council budgets, elections results from the Electoral Commission of Zambia, and poverty data from World Bank (2015). Mayor's party affiliation is based on 2016 local elections unless there was a by-election since then and before December 2018.

Notes: *Budget data is from IFPRI-UNZA Zambia Local Bureaucrats survey rather than from council budgets and only for 2018. "Goods and services" include office costs (internet, computer, telephone charges); building, repair and maintenance costs; plant, machinery, vehicle running and maintenance costs; other administrative operating costs; requisites (e.g. street lighting equipment, insecticides, water treatment chemicals, protective clothing, etc.); services (e.g. cultural promotion, consultancy fees, state functions, land demarcation and survey); travel expenses; training; and legal costs. 
Across these councils, 153 bureaucrats from the administrative wing were surveyed to gain insights about morale, career commitment, and service delivery constraints. ${ }^{7}$ As Finan et al. (2017) note, there is very little analysis of mid-level bureaucrats in developing countries. This gap is even more pronounced for scholarship looking at the impacts of decentralization, which is puzzling given that local government bureaucrats play such a critical role at overseeing local service delivery. To be inclusive of the wide range of actors who are key for local government in Zambia, staff were interviewed from predominantly six departments: town clerk's office, finance department, human resources and administration, public health services, housing and social services, and development planning (see Table 2). Specific questionnaire modules were developed for particular departments, including a section on revenue and expenditures for respondents in the finance department, and a focus on waste and market management for those in the departments of public health and housing and social services, which house the Solid Waste and Market Units, respectively. To the broadest extent possible, interviews were conducted with those at different levels of seniority. Approximately 26.1 percent could be classified as high-level managers and included Town Clerks and Council Secretaries as well as Directors and Deputy Directors of a department. Another 45.8 percent of the sample included mid-level civil servants while lower-level employees, including those who are members of Zambia United Local Authority Workers' Union (ZULAWU) or work as market masters, constituted the remaining 28.1 percent of the sample.

Table 2: Range of departments in sample

\begin{tabular}{|l|c|}
\hline Departments & Share \\
\hline Town clerk's office & 7.2 \\
\hline Finance department & 20.9 \\
\hline Human resources and administration & 16.3 \\
\hline Public health services & 15.0 \\
\hline Housing and social services & 13.1 \\
\hline Planning & 22.9 \\
\hline Other & 4.6 \\
\hline N & 153 \\
\hline
\end{tabular}

Source: IFPRI-UNZA Zambia Local Bureaucrats survey

Notes: ${ }^{a}$ Other category includes Engineering department, Institutional Management department, Works department and Public Relations department

This survey was then complemented with in-depth interviews with 17 elected ward councilors across 11 different districts to better understand the politician-bureaucrat relationship. The councilors selected also serve on their districts' waste and/or market managements committees so could speak to issues in those services areas. In the four cities within the sample, interviews were also conducted with a

\footnotetext{
${ }^{7}$ All surveys were conducted in English, which is the official language of Zambia and one in which all civil servants need to be fluent.
} 
total of 26 market chairpeople across 20 markets as well as with 5 private waste collection companies (CitiMop, Chachi Waste Solutions, Rojo Environmental Management Systems, Professional Waste Solutions, and Keli Clean). These interviews allowed for probing how well incentives are aligned across different sectoral domains relevant for managing Zambia's urbanization.

\section{Overview of Bureaucrats: Background, Motivation, and Satisfaction}

As seen in Table 3, women constituted about 39 percent of the sample and tended to be more concentrated in mid- and lower-level positions. While most of those in director level positions were 35 years-old or older, those in other positions fell predominantly into the 25-34 or 35-44 cohorts. Not surprisingly, those with higher job positions had a higher level of education. Respondents collectively had attended a diverse range of academic institutions (see Appendix), which is important to mitigate the influence of "groupthink" and thereby foster creativity and innovation in the workplace (Jackson 1995; Janis 1982). More than 60 percent of the sample had at least one other member of their immediate family who was also a government employee. Of those who did, respondents on average had three family members who were, or had been, government employees. While those at the director level had on average worked for local government the longest at about 199 months (or over 16 years), many at this level were relatively new in their council compared to their colleagues.

Table 3: Demographic, Educational, and Familial Background of Bureaucrats (\%)

\begin{tabular}{|c|c|c|c|c|}
\hline Variable & Director & Mid-level & Lower level & Total \\
\hline Female & 22.5 & 41.4 & 51.2 & 39.2 \\
\hline \multicolumn{5}{|l|}{ Age group } \\
\hline $18-24$ & 0 & 1.4 & 7.0 & 2.6 \\
\hline $25-34$ & 10.0 & 44.3 & 46.5 & 36.0 \\
\hline $35-44$ & 40.0 & 37.1 & 37.1 & 37.3 \\
\hline $45-54$ & 35.0 & 14.3 & 9.3 & 18.3 \\
\hline 55 and above & 15.0 & 2.9 & 2.3 & 5.9 \\
\hline \multicolumn{5}{|l|}{ Education } \\
\hline Craft certificate or diploma (2 years) & 7.5 & 11.4 & 55.8 & 22.9 \\
\hline Bachelor's level (4 years) & 45.0 & 77.1 & 44.2 & 59.5 \\
\hline Master's level & 47.5 & 11.4 & 0.0 & 17.6 \\
\hline $\begin{array}{l}\text { Have at least one other family } \\
\text { member who works/worked in } \\
\text { government }\end{array}$ & 52.5 & 67.1 & 62.8 & 62.1 \\
\hline $\begin{array}{l}\text { Average number of months in local } \\
\text { government }\end{array}$ & 198.9 & 89.4 & 85.5 & 116.9 \\
\hline $\mathrm{N}$ & 40 & 70 & 43 & 153 \\
\hline
\end{tabular}

Source: IFPRI-UNZA Zambia Local Bureaucrats survey 
On the whole, these local government bureaucrats are not status-seeking individuals; instead of being focused on secure employment or the prestige of their jobs, most noted that they enjoyed their current position because it enabled them to use their expertise to design and implement programs ( 28 percent), allowed them to develop their skills at mentoring and managing staff (19 percent), afforded them opportunities to contribute to local government (19 percent), or engage with the community (18 percent). As seen in Table 4, most respondents generally were satisfied with their job functions. However, Table 4 also reveals that a much smaller proportion were satisfied with their wages and especially their non-wage benefits. This was particularly true for women. Pensions are a main source of contention due to the delays or non-payment of pensions by the councils to National Pension Scheme Authority (NAPSA). A reduction of payments to NAPSA, as well as to the Zambian Revenue Authority, are one tactic that councils use when they need to cover additional staff salaries. ${ }^{8}$

Table 4: Assessments of Job Satisfaction, share who agree (\%)

\begin{tabular}{|l|c|c|c|c|c|c|}
\hline Options & Director & $\begin{array}{c}\text { Mid- } \\
\text { level }\end{array}$ & $\begin{array}{c}\text { Lower } \\
\text { level }\end{array}$ & Male & Female & Total \\
\hline Satisfied with job & 89.5 & 85.5 & 76.7 & 86.7 & 80.0 & 84.0 \\
\hline Satisfied with wage & 47.4 & 43.5 & 37.2 & 48.9 & 33.3 & 42.7 \\
\hline $\begin{array}{l}\text { Satisfied with non-wage } \\
\text { benefits } \\
\text { (e.g. pension, training, etc.) }\end{array}$ & 39.5 & 29.0 & 51.2 & 44.4 & 28.3 & 38.0 \\
\hline N & 38 & 69 & 43 & 90 & 60 & 150 \\
\hline
\end{tabular}

Source: IFPRI-UNZA Zambia Local Bureaucrats survey

Notes: *The sample size deviates from 153 because a few respondents were too busy to address questions in the job satisfaction module of the questionnaire.

Another way of assessing morale is to inquire about job aspirations in the near future. When asked their career goals within the next five years, 60 percent noted that they would prefer not to work in local government (Table 5). Among the 40 percent of respondents who would like to stay in local government in some capacity, few wanted to stay in their current position and about a quarter claimed they would prefer to switch to a different area of expertise.

Table 5: Career aspirations within the next 5 years $(\%)$

\begin{tabular}{|l|l|l|l|l|}
\hline Aspiration & Director & Mid-level & Lower level & Total \\
\hline Continue in current position in local government & 10.0 & 5.7 & 2.3 & 5.9 \\
\hline $\begin{array}{l}\text { Advance to higher position in current area of } \\
\text { technical expertise in local government }\end{array}$ & 7.5 & 14.3 & 9.3 & 11.1 \\
\hline $\begin{array}{l}\text { Continue in local government but not in current } \\
\text { area of technical expertise }\end{array}$ & 12.5 & 25.7 & 30.2 & 23.5 \\
\hline Work for provincial government & 5.0 & 2.9 & 4.7 & 3.9 \\
\hline
\end{tabular}

\footnotetext{
${ }^{8}$ Interview with Council Secretary in Southern Province.
} 


\begin{tabular}{|l|l|l|l|l|}
\hline Work for national government agency or ministry & 22.5 & 20.0 & 20.9 & 20.9 \\
\hline Career in the private sector & 20.0 & 10.0 & 4.7 & 11.1 \\
\hline Career with an NGO or donor & 7.5 & 10.0 & 13.9 & 10.5 \\
\hline Career in university & 10.0 & 7.1 & 13.9 & 9.8 \\
\hline Retire from working & 5.0 & 2.9 & 0.0 & 2.6 \\
\hline Don't know & 0.0 & 1.4 & 0.0 & 0.7 \\
\hline N & 40 & 70 & 43 & 153 \\
\hline
\end{tabular}

Source: IFPRI-UNZA Zambia Local Bureaucrats survey

In terms of equipment, many respondents reported that they had enough access to electricity, printers, and computers to complete their work. One-third of the sample were, however, reliant on their own personal computers, which raises concerns about how sensitive council information not only is kept confidential but also is retained by the council even after a staff member has been transferred. Only 29.8 percent of the sample reported that they had sufficient council-provided internet access during the full eight hours of their working day; 41 percent claimed they never had internet access and instead had to rely on their personal data plans. New councils generally have worse infrastructure and working conditions than more established ones. The Pemba council, for instance, is split across three rented buildings, with staff spending much of their time walking up and down the Lusaka-Livingstone road to get their tasks completed. Despite being established in 2012, the staff is still waiting for their own consolidated office to be built.

\section{Rotation System and the LGSC}

As noted earlier, the re-establishment of the LGSC was intended to professionalize human resource allocations, including transfers, hiring, and promotions, at the local government level. To determine whether the LGSC mitigated against political interference in staffing decisions, respondents were asked directly the following two questions: 1) During the last 12 months, do you have any experience with elected officials, their appointees, or political party officials trying to influence any hiring decisions and/or promotions in your department/council?; 2) During your entire time in local government, do you have any experience with elected officials, their appointees, or political party officials trying to influence any hiring decisions and/or promotions in your department/council? Approximately 32.4 and 55.5 percent of the sample answered in the affirmative, respectively, to the two questions. Not surprisingly, those with a longer time in local government, especially five or more years, were significantly more likely to respond in the affirmative to the latter question.

Another concern was whether exposing corruption by colleagues or superiors could lead the whistleblower to be transferred. This has been a common use of transfers in other countries, like Ghana and India (Ayee 2013; Iyer and Mani 2012). Since such direct questioning may induce a response bias, especially if respondents are worried about revealing certain information, a list choice experiment was 
employed. List experiments aim to uncover truthful responses to sensitive information by using a treatment and control list of behavior options (see Gonzalez-Ocantos et al. 2012; Malesky et al. 2015). Following Brierley (forthcoming), the technique requires mitigating against floor effects (when a response is 0 ), which mean including behaviors that are entirely plausible so that respondents exposed to the treatment behavior are not worried about it being readily identifiable. In this case, "skills needed in another council" was included to avoid floor effects. Likewise, there is a need to avoid ceiling effects (when every item is possible), because respondents worry that if they agree with every item, then they are again admitting to the sensitive item. Consequently, "individual preference to live in a different council," which is not a likely reason for transfers, was included to mitigate ceiling effects. ${ }^{9}$ Table 6 shows the options that were provided. Exposure to the control or treatment was randomized.

Table 6: Options for List Experiment

\begin{tabular}{ll} 
Control & Treatment \\
\hline 1 Individual preference to live in a different & 1 Individual preference to live in a different \\
council & council \\
2 Skills needed in another council & 2 Skills needed in another council \\
3 Bad relationship with elected officials & 3 Exposed misconduct by colleague or \\
& supervisor \\
& 4 Bad relationship with elected officials
\end{tabular}

Notes: Respondents were asked "Please look at these options. Please tell us how many of these actions would cause a public servant in this council to be transferred to another council? Don't tell me which ones, but just please indicate how many of them are likely reasons." The questions were not asked to Town Clerks or Council Secretaries.

The impact of the experiment is estimated by taking the difference in the means between the treatment and control groups. The mean for the control and treatment were 2.15 and 2.46, respectively. As seen in Figure 3, the average treatment effect was 0.31 , meaning that 31 percent of the sample believe that exposing misconduct by a colleague or supervisor can lead to transfers. ${ }^{10}$ While this is not extremely high, it does mean that despite the LGSC, there is a still a perception that upholding accountability for good governance can be penalized with transfers.

\footnotetext{
${ }^{9}$ When asked whether respondents "are given the chance to communicate to the Local Government Service Commission their preference for their next council posting," 81 percent said they were not. This gives some confidence that individual preference to live in a different council is not broadly viewed as a valid reason for the transfers.

${ }^{10}$ See Appendix, Table A.2, for the balance tables for the list experiment.
} 


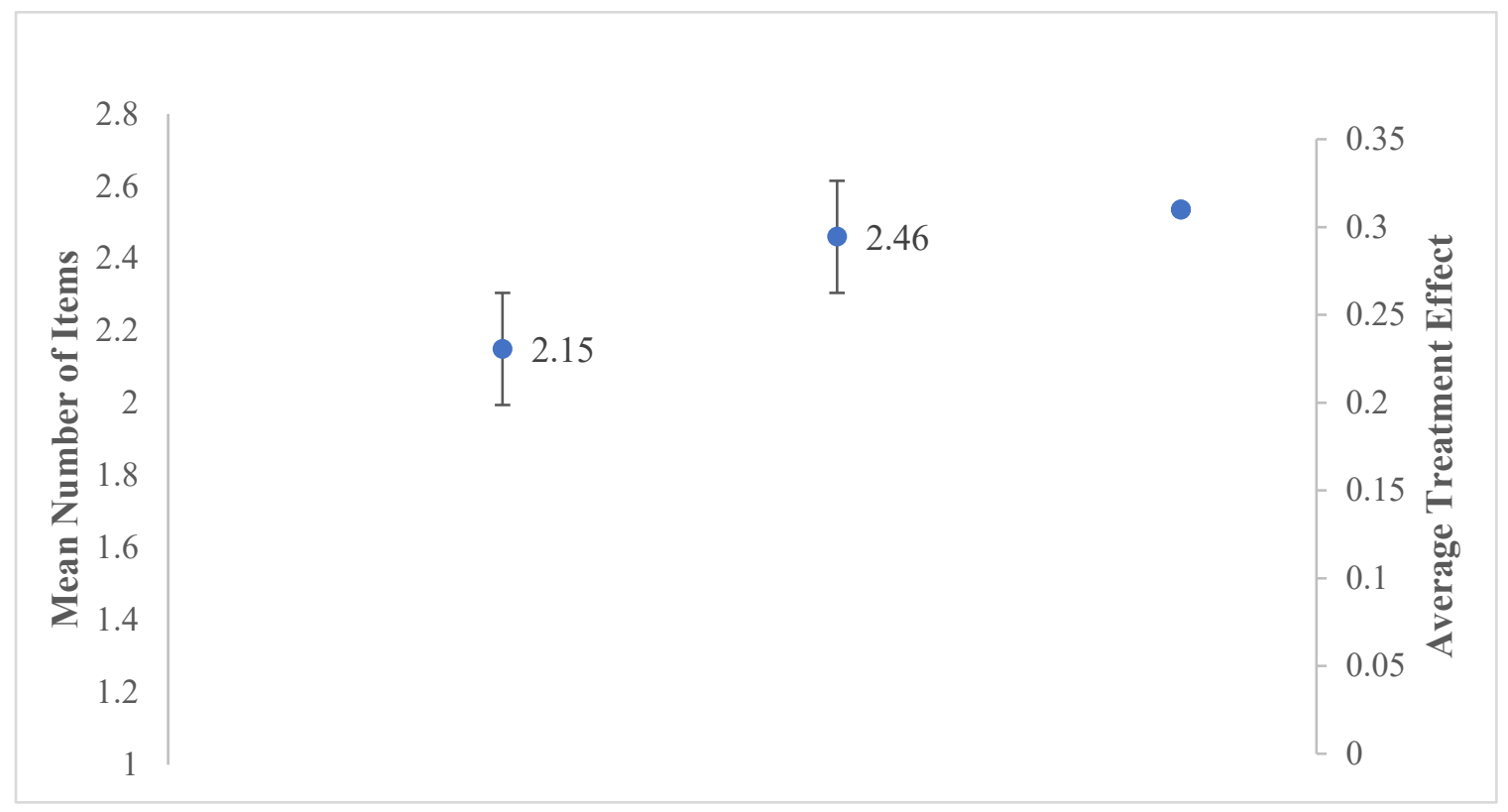

Source: Calculated from the IFPRI-UNZA Zambia Local Bureaucrats survey

A major implication of the LGSC is that local government civil servants are transferred across the country. According to the LGSC, the standard tenure length for being posted to a council is between three to five years. ${ }^{11}$ There can be many reasons for deciding where bureaucrats are moved, which include allowing staff who served in a rural council to move to an urban one, finding a council that can accommodate a bureaucrat who has been promoted to a higher position, or even medical requests by principal officers (e.g. Town Clerks and Council Secretaries). ${ }^{12}$ While many staff accept that their transfers are an anticipated part of their job and offer the opportunity to learn about diverse challenges facing Zambia, there are four key challenges to the current system. First, they do not receive much notice of the anticipated move, often receiving a letter that states that their transfer is to occur "with immediate effect." For instance, when asked why they believe they were assigned to their current posting, a Lusaka civil servant notes "I was in Monze for 4 days before I received a letter to move [to Lusaka]. I was just told and you can't say anything." A bureaucrat in Chilanga claims, "I was just transferred. We keep being moved around." In Ndola, a respondent answered the question by stating, "I have no idea. I just received my letter of transfer." In Choma, another noted that he had been moved four times in the last ten years. The LGSC claims the lack of advance notice is to prevent junior officers from lobbying the principal officers or politicians to stay in their current council. ${ }^{13}$

\footnotetext{
${ }^{11}$ Interview with the LGSC.

${ }^{12}$ Ibid.

${ }^{13}$ Ibid.
} 
As also observed by the Parliamentary Committee on Local Government (GRZ 2013), this can be difficult for marriages and families with school age children, especially if transfers involve relocating to a different province. As a result, a major compliant from interviewed bureaucrats is that many families are separated from each other, for either the workweek or for much longer periods. The LGSC acknowledges the problem and attempts to work with other service commissions (e.g. the Teacher Service Commission, Civil Service Commission) to keep families together if spouses work in education or for another branch of government, but it also emphasizes that there is no government policy that states workers should be together with their families. ${ }^{14}$

Of those who have had two or more jobs with the local government, 76 percent have moved to a different province for at least one of those jobs. Among those, 57 percent have moved to a nonneighboring province for at least one of those jobs. Figure 4 below further shows the tenure length based on examining the number of months respondents had been in their current job and their two immediately previous jobs, where applicable. The median length in these jobs was 18, 36, and 43 months, respectively, but the inter-quartile range is quite substantial, suggesting that there is a high level of variation around the LGSC's preferred tenure lengths.

Figure 4: Distribution of time in job position, three most recent local government jobs (Months)

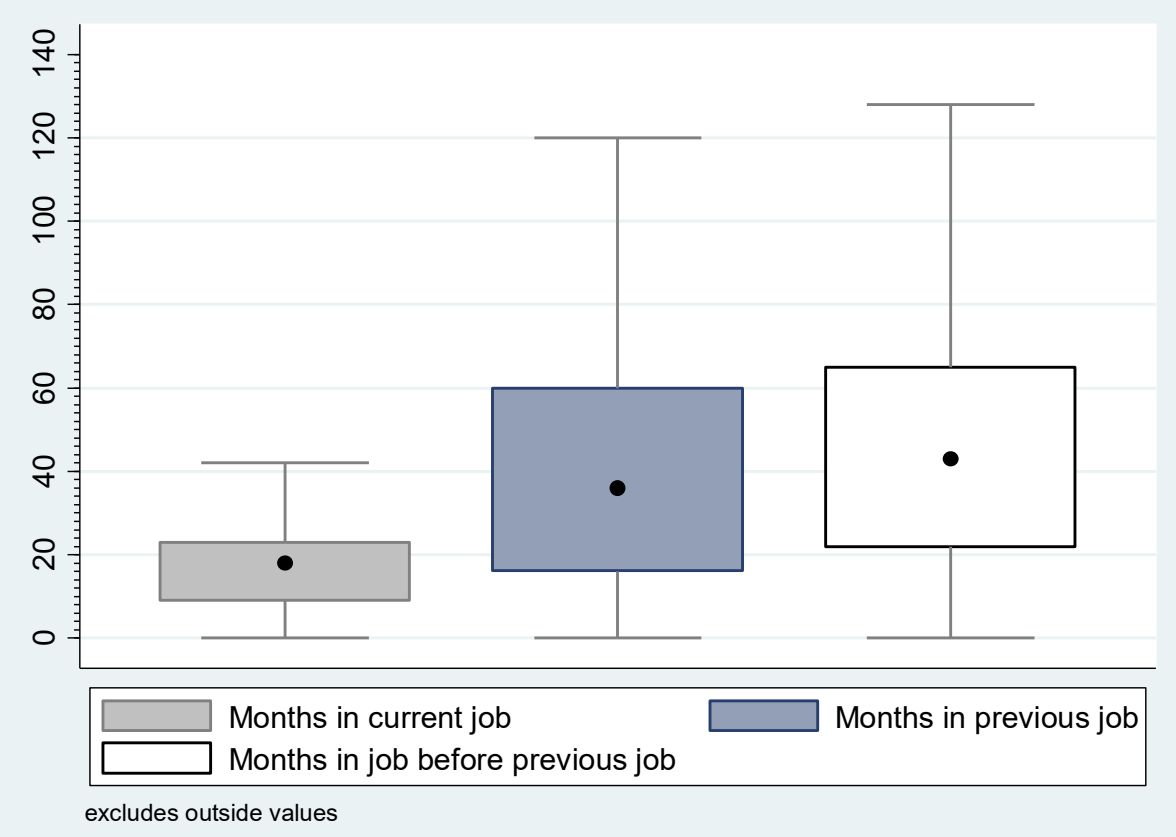

Source: IFPRI-UNZA Zambia Local Bureaucrats survey

Notes: For current job, N=153. For just two jobs, $N=111$. For three jobs, $N=69$.

\footnotetext{
${ }^{14}$ Interview with the LGSC.
} 
Second, staffing seems to be inappropriately targeted. Some councils are given too many staff of a particular position but not enough of another. Overstaffing was cited as a major concern, burdening the finances of the councils. The majority of staff wages are either paid out of own source revenue or from the share of the LGEF that is not allocated to capital expenditure. Consequently, overstaffing places a burden on scarce resources and infrastructure, especially in town councils. From the point of view of a council secretary in Southern Province, the transfers create "a challenge of office space and finance because we struggle with the payroll because the transfers come without corresponding funding. Just next door, there are four officers in just one office.” The misalignment of staffing with council needs and finances is a major concern that needs to be rectified.

Third, there is a lack of awareness of these changes by high level officials, particularly Town Clerks and Council Secretaries. Of the 12 who were interviewed in our sample, all said that they were only sometimes (33 percent) or never (66 percent) consulted about the transfers. A council secretary in Lusaka Province noted that he had only been in his position for 15 months but approximately 20 staff have left while 40 new staff have arrived. A municipal town clerk complained, "We have no say in decision making and get mediocre staff and then the council performs poorly yet [we are] blamed for such under performance." A city town clerk noted that there is turnover almost every week: "there is no notice [by the LGSC], we are just told." Another city town clerk concurred that the frequency of staff rotations was too high, unstandardized, and expensive. From the view of the LGSC, the councils are responsible for preparing their budget and ensuring that they have sufficient budgets for needed staff. Once the MLG approves those budgets, the council writes to the LGSC and requests the needed staff. ${ }^{15}$ Given these opposing perspectives between the principal officers and the LGSC, whereby the councils claim they are not informed of the transfers while the LGSC states they only recruit staff after it is requested by the councils, there appears to be a high level of miscommunication and mistrust over these processes

Fourth, there is a challenge of institutional memory that affects council functions, especially if a long period passes before a vacancy that was caused by a transfer elsewhere is filled. ${ }^{16}$ The bureaucrats play a central role with both ward councilors, citizens and the private sector. For instance, in Livingstone, which experienced a transfer of about 80 percent of its staff in 2017, with about 103 new staff estimated to have arrived since then, a ward councilor noted that "These transfers are difficult for the councilors because it leads to a loss of institutional memory." In Choma, a councilor who was elected in 2016 lamented that the council has received the wrong workers: "they [the council] may need an IT person but they [LGSC] send a surveyor instead." Similarly, a councilor in Chirundu claimed that the "LGSC keeps sending the wrong people," and note that this affects the work to be done in the community because a new

\footnotetext{
${ }^{15}$ Interview with the LGSC.

${ }^{16}$ In theory, civil servants can draft handover notes before they leave for their successor.
} 
person arrives and you need to review issues and actions with them again. In Kitwe, a ward councilor admitted that the LGSC seemed to have neither specific dates nor plans about transfers. Council secretaries and town clerks also emphasized that these transfers undermine the ability and incentive to make an impact and initiate programs. ${ }^{17}$

A few reasons were given for the frequency of transfers. First, the LGSC claims these are idiosyncratic because when the current LGSC was created in 2016, it performed an audit of the councils and discovered that many people had overstayed, and this was problematic for corruption. Therefore, a higher number of transfers were needed in 2017 to rectify a situation that had persisted for too long. ${ }^{18}$ Second, the explosion in the creation of new councils in the last few years has disrupted the system, requiring staff to be shuffled to fill in expertise gaps in the new councils. ${ }^{19}$ Third, some of the councils are in salary payment arrears, necessitating the LGSC to transfer them away precisely because of the burden that salaries place on own-source revenue. Fourth, given how disruptive they are, there is a belief that councils in opposition-held areas tend to be more targeted for transfers (see Zambian Observer 2019). There was no statistically significant difference in tenure length for those in UPND versus PF councils. However, the average tenure of those in UPND-held Livingstone is 18 months compared with 51 months in PF-held Kitwe and 30 in Ndola. Even if there is no clear evidence that councils are being politically targeted, there is a perceived arbitrariness of the LGSC's decisions that could be rectified with more transparency in decision making, and reducing the president's discretion to appoint LGSC commissioners.

\section{Misalignment between National and Local Government}

All of the councils have a common structure, including five-year strategic plans, weekly performance plans, and annual performance appraisals for staff. However, in terms of decision making on key issues, most lacked the genuine autonomy that is necessary to achieve actual devolution. This dynamic manifests in a few ways. The first is that council decisions are often delayed by the need to secure MLG approval. With respect to fiscal autonomy, councils are not able to adjust their tax rates without approval by the MLG. Bureaucrats resent this because it does not allow them to ensure they raise adequate revenue. As one council secretary noted, even to increase a tax on fruit vendors from K1 to K2 would require MLG approval. ${ }^{20}$ Ward councilors dislike this because they have no leverage to reduce

\footnotetext{
${ }^{17}$ Interviews with Town Clerks in Copperbelt and Lusaka Provinces.

${ }^{18}$ Interview with LGSC.

${ }^{19}$ The LGSC claimed that they strive to allocated more educated staff in the new councils to help them get started. However, we did not find this pattern in our sample.

${ }^{20}$ Interview with Council Secretary in Lusaka Province.
} 
levies on behalf of their constituents: "It's us councilors on the ground, we know how people live." ${ }^{21}$ Both scenarios create an impression that the MLG knows better than the local authorities about what rates are equitable to local citizens and what degree of revenue is needed to improve finances. In addition, when a motion is approved by the full council, inclusive of elected local officials, it then needs to go to the MLG for additional approval. When there are delays in receiving this approval from the MLG, ward councilors must explain to their constituents why development projects are taking longer than anticipated. ${ }^{22}$

The issuance or halting of directives by the MLG, without perceived consultation with the councils, represents a second area of constrained autonomy. For instance, in 2014, Circular No. 10 launched the establishment of sub-district ward development committees (WDC) as a modality for integrating community voices into the local government development and especially into strategic plans. This was then integrated into Article 152 of the 2016 Constitution. The councils were supposed to fund the creation of the WDCs using local revenue, part of their LGEF, and constituency development funds. ${ }^{23}$ Yet, amid forming these WDCs, another directive was issued in 2017 that called for councils to halt this process without offering an explanation. This has resulted in some wards having WDCs while others do not. No one interviewed understood why the process was halted. With the issuance of the 2019 Local Government Act, the process appears to have begun again with clear prescriptions from the MLG about the 13 types of representatives that needs to serve on the WDCs (GRZ 2019a).

A similar process has occurred with respect to the establishment of market management boards. In February 2017, the MLG announced the establishment of Market Boards. Based on the Markets and Bus Stations Act of 2007, markets and bus stations can either be managed by local authorities or through a management board. Since local authorities have been perceived as unable to execute this function appropriately and have allowed markets to be used as political battlegrounds, the Market Boards were supposed to be piloted in selected areas by June 2017 (GRZ 2017b). Many councils had provided nominations of individuals who could lead these boards, but most councils do not know why the nomination approval process seem to be languishing. ${ }^{24}$ Collectively, these issues indicate a lack of transparency in communication from the MLG about why decisions are reversed or why deadlines for implementation may be missed.

The issue of national level statutory instruments (SIs) that may not be locally appropriate or relevant was cited as a further example of top-down engagement by the MLG. One ward councilor noted how arbitrary and unexpected some of the MLG decisions appear to be: "There are a number of SIs where

\footnotetext{
${ }^{21}$ Interview with ward councilor in Southern Province.

${ }^{22}$ Interview with ward councilor in Southern Province.

${ }^{23} \mathrm{See}$ http://ie.ds.org.zm/index.php/phase-three/12-zambia-national-decentralisation-policy/62-establishment-ofward-development-committees-wdes.

${ }^{24}$ Interview with Town Clerk, Lusaka Province.
} 
the Ministry just wakes up and issues them." The SI No.10, officially known as The Local Government (Street Vending and Nuisances) (Amendment) Regulations, 2018, which was issued during the cholera crisis in 2018, repeatedly was identified as an area where the MLG seemed to impose a one-size fits all approach to a problem that was only relevant to a few city councils, especially Lusaka, where the outbreak was severe. This SI increased the penalties associated with street vending to improve food safety practices. In doing so, elected councilors believed that while it may have increased sensitization about safe food handling behaviors, it undermined the relationships that they had forged with street vendors in their communities and had negative impacts on vendors' livelihoods and families. A number of town clerks and council secretaries offered similar sentiments, with one noting, "The circulars are directed to all of us. They [MLG] give directives and tell you that you'll be disciplined if you don't conform. You actually have fear. If you don't do this, you'll be reported for disciplinary reasons.” ${ }^{25}$ In July 2019, the MLG reversed course and issued another decree to allow street vendors to trade freely in the streets (Lusaka Times 2019), reinforcing the perception that local authorities have little autonomy to deal with local development issues.

The devolution process that commenced in 2015 is another key source of contention.

Increasingly, staff from the key sectors that were slated for devolution, such as agriculture, education, and health, report on their activities during full council meetings and may engage in weekly or quarterly meetings with the councils. However, funding for most devolved services still originates from the sectoral line ministries so they are not the result of collective decision making processes within the councils. This dynamic results in accountability upwards to the national ministries, via the district and provincial commissioners, rather than downwards to the councils and as such, the activities of these staff are not viewed as central to the councils. A further area of contention is that the salaries of staff from the devolved sectors have not been harmonized since they continue to report to the Public Services Commission rather than the LGSC. One director even lamented, "How can a town clerk be responsible for someone who earns a higher salary than him?" 26 This challenge was also observed by the Parliamentary Committee on Local Governance undertaken in 2017 at the supposed end phase of the devolution process; at that time, the Committee noted its concern that uneven salary structures risked demotivating affected employees (GRZ 2017a). At the time of writing in 2019, the problem continues to persist.

\section{Mismatched incentives between bureaucrats and politicians}

${ }^{25}$ Interview with Council Secretary, Southern Province.

${ }^{26}$ Interview with Director of Engineering, Southern Province. 
Globally, the relationship between the administrative and political wings of local government is central to a functioning decentralized system. Ideally, the expertise of professional bureaucrats is blended with the preferences of elected officials, who presumably advocate on behalf of local citizens. To be effective, local government needs to ensure that bureaucrats remain accountable for policy decisions but not subject to political interference that undermines their competence (Ejersbo and Svara 2012).

Zambia follows what Dasandi and Esteve (2017) call the "intrusive model" of politicalbureaucratic relations whereby there is a strict separation between the administrative and political wings, but bureaucrats have relatively low levels of autonomy since their decisions can be bypassed by political actors. Table 7 shows that the relatively strict hierarchy of administration means that few mid- and lowlevel civil servants have opportunities to engage with either their Town Clerks and Council Secretaries or with the Mayors and Council Chairpersons. This means that mid-level managers and low-level technical staff, who often are not from the council in which they work, may miss out on opportunities for engagement that would allow for a better understanding of local development priorities.

Table 7: Levels of Bureaucrat-Politician Engagement, by Position Level (\%)

\begin{tabular}{lccccc}
\hline \multicolumn{5}{l}{ How often do council bureaucrats interact with the Mayor for reasons related to their job? } \\
\hline & Town Clerk & Director & Mid-level & Lower level & Total \\
Never & 0.0 & 18.5 & 42.6 & 72.1 & 43.6 \\
Rarely & 0.0 & 40.7 & 35.3 & 11.6 & 26.8 \\
Several times a month & 36.4 & 37.0 & 17.7 & 14.0 & 21.5 \\
Always & 63.6 & 3.7 & 4.4 & 2.3 & 8.1 \\
N & 11 & 27 & 68 & 43 & 149
\end{tabular}

\begin{tabular}{lccccc}
\hline $\begin{array}{l}\text { How often do council bureaucrats interact with the elected Ward Councilors for reasons related } \\
\text { to their job? }\end{array}$ & Town Clerk & Director & Mid-level & Lower level & Total \\
\hline & 0.0 & 7.4 & 13.2 & 32.6 & 16.8 \\
Never & 81.8 & 40.7 & 22.1 & 30.2 & 32.2 \\
Rarely & 0.0 & 40.7 & 42.6 & 32.6 & 36.2 \\
Several times a month & 18.2 & 11.1 & 22.1 & 4.6 & 14.8 \\
Always & 11 & 27 & 68 & 43 & 149
\end{tabular}

Source: IFPRI-UNZA Zambia Local Bureaucrats survey

Notes: The sample size deviates from 153 because a few respondents were too busy to address questions in the council affairs module of the questionnaire.

Category definitions: Never -0 interactions in a month; Rarely -1 interaction in a month, quarterly interaction, only when the need arises; Several times a month -2 to 16 interactions in a month; Always -16 or more interactions in a month, daily engagement

In addition, it leads to misunderstandings and mistrust. On the one hand, interviewed bureaucrats routinely noted that ward councilors undermined their authority by going directly to the Mayor/Council Chairperson if they disagreed with a decision that a bureaucrat made. This was noted with respect to many areas, including decisions over the allocation of land plots, the use of council vehicles, the 
enforcement of regulations, the choice of procurement suppliers, and decisions over who to hire as general workers. One civil servant noted, "In performing constitutional duties there is much political interference. For example we can close illegal bars today but you just receive directives to open it." 27 Others observed that "If you advise from a professional point of view, they don't agree with you and go behind your back to the mayor" 28 and "They [ward councilors] try to override or overlook the decisions that you have made as head of department so much so that they would like to achieve their intended goal even if it would not benefit the institution at the end of the day. When you advise as a technocrat, they feel you are undermining them." 29

On the other hand, the ward councilors believe that they are sometimes ignored by the civil servants due to disparities in education levels: "We thought it was us, as councilors, who were responsible for making by-laws. But sometimes we feel overpowered. The ward councilors are not educated. The council staff are better educated and we sometimes feel left out and not respected. Despite what we were told at the MLG orientation trainings, we are not that independent to make decisions." 30 Indeed, while a majority of the bureaucrats had completed a bachelor's degree (see Table 3), the average ward councilor had a craft certificate or diploma. However, they were predominantly from the district in which they now serve, often work in agriculture, education, or trade and therefore, believe that they are more attuned to community needs. As noted above, one area of contention is the enforcement of SIs by bureaucrats even if they are harmful to the interests of citizens.

\section{Urban Service Provision}

The dynamics noted above have serious implications for service delivery in Zambia, especially in the country's urban areas where both politics can be more pronounced and population pressures create a burden on already stretched services. Consequently, two service delivery areas, which are closely interconnected, were analyzed: markets management and waste collection. Unlike more recently devolved responsibilities in the education, agriculture, and health sectors, these two areas have long been constitutional responsibilities of district councils and centrally critical to Zambians' livelihoods, health, and environment. Moreover, even though this study does not provide a detailed survey analysis of citizen perspectives about Zambia's decentralization process, interviews with market committees and waste management service providers offer some insights into citizen experiences with local government among an important sub-sample of the urban population. More specifically, 81 percent of urban Zambians labor in the informal economy and approximately 55 percent in the non-agricultural informal sector (GRZ

\footnotetext{
${ }^{27}$ Interview with Director of Public Health, Central Province.

${ }^{28}$ Interview with Director of Engineering, Lusaka Province.

${ }^{29}$ Interview with Director of Housing and Social Services, Southern Province.

${ }^{30}$ Interview with ward councilor, Southern Province.
} 
2015). Markets not only are a major source of income for those in the urban informal economy but also serve as centers of commodity value chains, thereby exerting important linkages with rural, regional, and global economies. In addition, they constitute a critical source of revenue for the city councils. For example, in Lusaka, the estimated revenue collected from market fees alone in 2018 was about 10.5 percent of the city's own-sourced revenue. ${ }^{31}$ Due their economic importance, city markets often represent politically contested spaces where ward councilors, market committees, informal traders' associations, party cadres, and bureaucrats from the councils frequently interact over how revenue is mobilized and distributed.

With respect to waste, a number of initiatives have been pursued in recent years, including the Keep Zambia Clean, Green, and Healthy Campaign. Nonetheless, with rapid urbanization, coverage and collection of waste remain low, especially in shanty compounds and markets. Insufficient trash collection results in soil contamination and clogged drains, contributing to floods and water-borne diseases, such as cholera and typhoid while informal trash burning in compounds contributes to upper respiratory illnesses. In 2016, Zambia's waste generation rate was $0.51 \mathrm{~kg} / \mathrm{capita} /$ day, slightly higher than the regional average of $0.46 \mathrm{~kg} /$ capita/day. As of 2004, the Environmental Council of Zambia reported that only 20 percent of the national population and 10 percent of Zambian households received waste collection services, while in the capital city of Lusaka, 18 percent of the population reported waste collection services (Kaza et al. 2018). More than a decade later, 45 percent of Lusaka had waste collection coverage, which indicates an improved but still highly insufficient level of coverage (Kaza et al. 2018).

\section{Markets Management}

Surveys were conducted with 26 market committee chairpeople across 20 markets spanning Kitwe, Livingstone, Lusaka, and Ndola. Table 8 provides the names of the surveyed markets and highlights that surveys were conducted with both very large and very small markets across the cities to assess variation in service delivery. Zambia has a mixture of governance structures within the markets, including those that are run by councils, cooperatives, and public-private partnerships. Given the focus of the study, only council markets were targeted for inclusion. ${ }^{32}$ In addition, detailed survey modules were conducted with bureaucrats in the Department of Housing and Social Services (DHSS) in the four cities and with the market managers who oversee the markets on behalf of the DHSS.

\footnotetext{
${ }^{31}$ Calculated from council budget data collected during fieldwork.

32 In some markets, there are multiple governance structures. Kamwala, for example, has a section that is councilrun as well as a section that is under the public-private partnership with a Chinese company.
} 
Table 8: List of Surveyed Markets

\begin{tabular}{lll}
\hline Market Name & City Council & $\begin{array}{l}\text { Approximate } \\
\text { Number of } \\
\text { Traders }\end{array}$ \\
\hline Buchi Kamitondo & Kitwe & 1250 \\
Buchi Market & Ndola & 350 \\
Chifubu Formal Market & Ndola & 600 \\
Chifubu Modern Market & Ndola & 2500 \\
Chifubu Market & Kitwe & 1480 \\
Chilenje & Lusaka & 1000 \\
Chisokene - Market A & Kitwe & 5000 \\
Chisokene - Market B & Kitwe & 9000 \\
Chisokene & Ndola & 1200 \\
Dambwa Central & Livingstone & 500 \\
Kamwala & Lusaka & 5000 \\
Kaunda Square Stage One & Lusaka & 1000 \\
Kitwe Main Bus Station & Kitwe & 525 \\
Linda Market & Livingstone & 80 \\
Main Masala Market- Market C & Ndola & $2500-2800$ \\
Maramba & Livingstone & 800 \\
Matero & Lusaka & 1000 \\
Mbita & Livingstone & 600 \\
Old Nakadoli & Kitwe & $1600-2800$ \\
New Nakadoli & Kitwe & 2500 \\
Source: IFPRI-UNZA market chairperson interviews, March 2019. Number of \\
traders are approximations provided by interviewees. \\
\end{tabular}

To facilitate the smooth running of the market spaces, there ought to be an adequate provision of basic services such as water, drainages, and fire safety, inter alia, that are vital to the everyday running of the markets. The provision of these services is the mandate of the Local Government under the Local Government Act Number 2 of 2019 Part II section 16, which outlines the functions of the local authorities. The markets are managed by market masters employed by the council under the Act who are appointed by and responsible to the local authority via the councils' market managers. At the same time, revenue officers who collect fees and levies on a regular basis are accountable to departments of finance. Most markets also have their own committees whose leadership are elected by their peers and who serve as a critical liaison between the traders, the market masters, and the broader council.

Electricity represents the most readily available service in the markets with almost all markets noting that it is not a problem for individual shops. However, communal lighting that can be used in the markets at night was less readily available, with negative implications for safety and security at night. About 88.5 percent of market chairpeople also contend that there is clean running water available in the markets, though a number noted that the supply was erratic. At the other extreme, very few of the surveyed markets had functioning fire extinguishers, which is problematic given the number of fires that 
have plagued urban markets in recent years. Drainage is another common problem, especially in the rainy season. While some sections of markets studied do not flood due to natural factors such as gradient of the slope, many existing drainages are too decrepit, shallow and/or narrow. As a chairperson of Kamwala market noted, "Drainage is pathetic," while in Chifubu Market, a respondent confirmed, "This is the biggest challenge. There is no proper drainage in this market. We suffer serious floods." ${ }^{33}$

When asked their top three priorities for improvement in the markets, toilets and waste collection were identified by 46 and 50 percent of respondents, respectively. The availability of functioning toilets is an almost universal problem in the markets. Nakadoli is one of the most extreme with no flushable toilet for its approximately 2500 traders. Similarly, Chisokone market has only two toilets to serve over 5,000 traders, forcing people to resort to using alternative and unhealthy means. In Main Masala Market, there is one toilet that was closed down at the time of fieldwork. Even where the ratio of toilets to traders is bit better, many of the sanitation systems have not been updated to cater for the growing population of traders, often resulting in blocked pipes that render the toilets unusable for extended periods of time.

Many of these deficiencies are interconnected. Poor drainage, coupled with substandard toilet facilities, can all exacerbate cholera outbreaks, threaten food safety, and undermine the contribution of markets to urban aesthetics. This is compounded by the uneven nature of waste collection across the markets. For half of the market sample, waste collection occurs every day or one or more times a week. This includes some of the largest markets in their respective cities, such as Chisokone and Kamwala. In Lusaka's Kamwala market, where waste is collected three times a week, the market committee established a garbage management committee that amasses trash in a common location and contracted, through the council, a private company to collect. ${ }^{34}$ For the remainder of the sample, collection is either twice a month or even less frequently. In one of the capital city's other markets, Matero, collection had stalled for a month at the time of fieldwork: "It [waste collection] used to be frequent. But there is problem with the council. They say they don't have capacity and lack fuel." 35

How effectively do councils respond to markets' service delivery shortfalls? In almost all markets, chairpeople noted that they feel very comfortable speaking openly to their councils about these service delivery challenges and rely on both written letters, visits to council offices, and engagement with market masters. Not surprisingly, where market masters have offices in the markets rather than within their councils, the level of communication is perceived to be much higher. However, where they are not present, the impression is that while council visits for revenue collection are frequent, engagement on service delivery issues only occurs when a problem has been reported rather than to maintain services or

\footnotetext{
${ }^{33}$ Market chairperson in Kamwala and Chifubu Markets in Lusaka and Kitwe, respectively.

${ }^{34}$ Interview with member of Kamwala market committee.

${ }^{35}$ Interview with member of Matero market committee.
} 
proactively anticipate challenges, such as checking on drainage infrastructure in advance of the rainy season.

There are four main bottlenecks that hinder responsiveness. First, there is a lack of manpower in terms of numbers of market masters and general workers. Market chairpeople complained of general workers not reporting for work or requiring daily supervision by market masters. ${ }^{36}$ The latter is especially relevant for waste collection since general workers typically assist with sweeping and cleaning the markets. Since marketeers pay for the service, they believe that the council should employ adequate staff for the service. ${ }^{37}$

Second, a major area of discontent, particularly in Lusaka and Livingstone markets but less so for those on the Copperbelt, is the lack of consultation by the councils on fees and levies. In turn, the fact that such revenue is not earmarked by councils for reinvestment into the markets makes the lack of consultation more frustrating. For example, the market committee in Kamwala lamented that "The LCC collects for the ablution blocks but don't put the money back in maintaining them." 38 This claim is not unfounded; budget data for Lusaka show that while more than K35 million was estimated to be collected from the markets in 2018, the Lusaka City Council only allocated K9.6 million for expenditures on those markets. ${ }^{39}$ Earmarking a larger share of the revenue collected in the markets for only investment in the markets is institutionally challenging. As noted by one director of DHSS, if the money for markets goes into a separate account, all departments will argue for the same practice, thereby undermining the ability of councils to scale up their revenue. ${ }^{40}$

Third, council staff within the DHSS can play a critical role for the marketeers and therefore, staff transfers have non-negligible externalities. In Mbita Market, the market committee believes that dramatic improvements in waste collection can be attributed to the new set of bureaucrats who arrived after the previous staff were transferred and who are perceived as more proactive..$^{41}$ By contrast, however, others believe the council transfers, especially market masters and those more senior within the DHSS, stymie momentum towards achieving improved services that have taken a while to negotiate. ${ }^{42}$

Fourth, the presence of party cadres in markets exacerbates their politicization. Common complaints against cadres include receiving payment for waste collection that they never ultimately do, allocating stalls they did not legally own to marketeers in exchange for rental payments, and allowing vendors to illegally build makeshift stalls on the streets. Yet, council staff seem powerless to halt these

\footnotetext{
${ }^{36}$ Matero market committee member, Lusaka.

${ }^{37}$ Chifubu market committee representative, Kitwe.

${ }^{38}$ Kamwala market committee representative, Lusaka.

${ }^{39}$ Council budget data collected during fieldwork.

${ }^{40}$ Director of Department of Housing and Social Services, Southern Province.

${ }^{41}$ Mbita market committee member, Livingstone.

${ }^{42}$ Matero and Kamwala market committee representatives, Lusaka.
} 
dynamics. Among surveyed market chairpeople, cadres were most frequently identified as problematic on the Copperbelt, as expressed by those in Chisokone market in Kitwe: "The biggest challenge is the cadres who are largely collecting huge amounts from our market. This is reducing council revenue collection. If the cadres can be removed or regulated in the markets, we can operate effectively." 43 Similar sentiments were heard by the committee of Ndola's Chisokone market:

Garbage collection is a major challenge we are experiencing in this market. As you can see outside, garbage has piled and remains uncollected for close to three weeks now. We always contribute money towards garbage collection in this market, but the private waste collectors hired by cadres complain of not being paid on time as a result, garbage is not collected on regular basis. The Council has tried to control the situation, but it seems they have failed. ${ }^{44}$

In Livingstone and especially Lusaka, cadres were identified as problematic by those in the DHSS and ward councilors. In fact, among the 15 surveyed bureaucrats from the DHSS, all but one agreed or strongly agreed that party cadres were problematic in their council. One bureaucrat recalled that cadres asked him to transfer a market master because the latter refused to give the cadres a portion of the collected revenue. ${ }^{45} \mathrm{~A}$ few responded that nothing can be done to tackle the problem because they fear the cadres will communicate with the LGSC to have them transferred. ${ }^{46}$

The MLG has attempted to establish market boards under Statutory Instrument No. 77 of 2017 rather than allowing the councils to directly run them. The justification for the boards, an idea first promoted in 2007, is that the councils are allowing illegal collections of levies from marketeers (GRZ 2018c). As noted earlier, the implementation of such boards appears stalled, even in the set of councils that were targeted as pilot areas by MLG. ${ }^{47}$ More significantly, however, the idea of removing such an important source of revenue from the councils is akin to recentralization. Rather than reducing the councils' mandate in this area, greater political will by national and local party officials to restrain the activities of their cadres would be a more sustainable solution.

\section{$\underline{\text { Waste Collection }}$}

The previous section illustrates that market management and waste collection are closely intertwined. To further understand how the context of decentralized government affects waste collection challenges in both urban markets and households, additional interviews were conducted with bureaucrats

\footnotetext{
${ }^{43}$ Chisokone market committee member, Kitwe.

${ }^{44}$ Chisokone market committee member, Ndola.

${ }^{45}$ Department of Housing and Social Services, Lusaka Province.

${ }^{46}$ Department of Housing and Social Services, Lusaka Province.

${ }^{47}$ These councils include Chipata, Choma, Kitwe, Livingstone, Lusaka, Mazabuka, Ndola, and Samfya (GRZ 2018c).
} 
in the solid waste units of the council departments of public health, ward councilors on the councils' public health committees, and private waste collection companies.

Zambia's major cities are divided into waste management zones that are then each serviced by one of three types of providers (Muller et al. 2017). In town councils, most of the waste collection services are conducted solely by the council. However, the majority of city and municipal councils use a mixture of public and private activity, with councils contracting private waste companies to service low density urban zones and some markets while maintaining authority over the profitable central business district (CBD). Furthermore, in the city councils, there is a prevalence of community-based enterprises (CBEs) that service the high-density, less profitable peri-urban areas that are difficult to access by the larger franchised companies. In Lusaka City Council, there are over 100 CBEs collecting waste from these poorer areas, while in Livingstone City Council there are five. ${ }^{48}$

This diversity in approaches results in a highly inequitable level of waste collection, with the more affluent households and commercial businesses receiving better coverage by private and council collectors than high density compounds, which must rely on CBEs that can vary dramatically in terms of their expertise, commitment, and capacity. Collection rates vary drastically based on location within the council, with the $\mathrm{CBD}$ receiving higher rates of collection relative to the poorer residential communities. A bureaucrat from Livingstone City Council noted that collection rates for the CBD were around 90 percent, around 60 percent for the low-density urban areas, and only at 30 percent for the high-density peri-urban communities. ${ }^{49}$ Ward councilors on their councils' public health committees confirmed that the focus of public council collection is on major public spaces, contributing to a large degree of spatial inequality in waste collection services. ${ }^{50}$

The high costs of waste collection underlie this three-tiered system. Waste collection is expensive, requiring dump trucks that are almost exclusively imported second-hand from overseas, fuel, and protective clothing. For a company such as Citimop, monthly costs of collection in 2019 were approximately K463,000. ${ }^{51}$ For council-collected trash in the capital, an estimated K52,000 is spent daily by the LCC just on fuel. ${ }^{52}$ Smaller councils have fewer people to service but face distinct challenges. For example, Zimba lacks a fueling station so, waste collectors must travel to the neighboring Livingstone or Kalomo councils to obtain fuel, increasing the overall costs of an already squeezed budget. ${ }^{53}$ In Chilanga,

\footnotetext{
${ }^{48}$ Acting Director for Public Health in Lusaka and Senior Health Inspector in Livingstone

${ }^{49}$ Interview with a Senior Health Inspector in Livingstone City Council

${ }^{50}$ Interview with a ward councilor in Kitwe City Council and Kabwe Municipal Council

${ }^{51}$ Director of Citimop, Lusaka.

52 Interview with Department of Public Health, Lusaka City Council

${ }^{53}$ Interview with a ward councilor in Zimba town council
} 
only one ward had access to solid waste disposal; the remainder of the council's residents throw their rubbish along streets or dig pits and burn it. ${ }^{54}$

Oversight of franchises and CBEs is critical, and the councils have different mechanisms for achieving this, including performance appraisals based on achieving particular targets and officers stationed at solid waste sites and weighbridges to monitor how many vehicles arrived. In some cases, regularly organized meetings with solid waste units of the councils allow for a review of performance and identification of strategic goals. Yet, staff turnover by the LGSC has affected this dynamic. The director of one of the eight franchise companies in Lusaka noted that the scheduled quarterly meetings with the Waste Management Unit within the city council had reduced due to staff turnover at the $\mathrm{LCC}^{55}$. With the transfer of important staff out of the unit and the arrival of new employees, a more ad hoc meeting system emerged. Such instances underscore that human resource challenges in the form of excessive staff transfers result in inadequate knowledge transfers that adversely affect service delivery.

Councils' own-sourced revenue covers most, if not all, of the budgets for council waste collection, with little funding support from the central government. In a town council in Central Province, the central government only contributed 20 percent of the waste management budget in 2018, while in a sampled city council, more than 90 percent of the funding for waste collection came from the council's generated revenue. ${ }^{56}$ As expressed by a director in Lusaka City Council, "Our revenue just covers our monthly bill for salaries and what comes from government is less than a quarter of the monthly wage bill; but then how do [we] pay for the services?"57

The lack of council financing for waste is partially tied to the unwillingness of citizens to pay for waste, or the inconvenience of doing so. For publicly provided services, most councils require subscribers to make monthly visits to the council building to make the payment. If citizens fail to do so, several councils send out revenue officers to collect the fee door-to-door. ${ }^{58}$ Similarly, those who receive services from franchised private companies must pay them directly at their offices. For residents who cannot access the pay site, some companies enlist a revenue collector to gather fees house to house. In Lusaka, a pilot scheme had been initiated in a few compounds where waste collection fees were bundled with water tariffs so that a proportion of payments for water go towards waste. ${ }^{59}$

Political interference is also quite pronounced. For instance, scaling up the Lusaka tariff bundling scheme, or instead bundling waste fees with mobile phone talk time, has met political resistance. ${ }^{60}$

\footnotetext{
${ }^{54}$ Ward Councillor, Chilanga council.

${ }^{55}$ Interview with the Director of Citimop in Lusaka City Council

${ }^{56}$ Ward councilor in Chisamba and Department of Public Health in Lusaka

${ }^{57}$ Interview with Department of Public Health, Lusaka City Council

${ }^{58}$ Interview with Chief Health Inspector in Lusaka Province

59 Town Clerk, Lusaka.

${ }^{60}$ Solid Waste Management Unit, Lusaka.
} 
Some council bureaucrats lament that ward councilors broadly oppose forcing poorer residents to pay for their waste collection. ${ }^{61}$ On the Copperbelt, it was similarly perceived that "Issues to do with waste management service are always characterized with political interference." ${ }^{22}$ Ward councilors though face a difficult situation since they are the only ones vulnerable to sanctioning by citizens through elections; councilors are blamed by citizens if rates go up or if waste is not collected, which motivates their interference. ${ }^{63}$

Given the challenges faced by local authorities in collecting waste, Cabinet approved in 2018 the introduction of a bill to establish an autonomous Solid Waste Management Utility. The intention of this proposed agency would be to incorporate solid waste management companies, outline their functions, oversee their licensing, and be responsible for their regulation, construction, and maintenance of landfills and other disposal facilities. In this way, the responsibilities of the councils for waste management would be reduced (Lusaka Times 2018c). As with the introduction of Market Boards, such initiatives suggest a recentralization of a critical council responsibility that contradicts current rhetorical commitments toward greater devolution.

\section{Conclusions and policy recommendations}

Although decentralization can be viewed as a technical exercise resulting in the transfer of functions, staff, and finance to subnational authorities to improve services and accountability, it is an inherently political undertaking that requires reconciling trade-offs in interests and incentives across levels of government and between politicians and bureaucrats. These political economy issues can serve as a binding constraint that conditions many of the other inadequacies observed globally with the implementation of decentralization efforts (Eaton et al. 2011; Smoke 2015). Few studies, however, look at these challenges from the perspective of local bureaucrats who are centrally responsible for implementing policies and programs that affect service provision. This paper addresses this gap by providing empirical analysis based on surveys with over 150 local government bureaucrats across 16 diverse councils in Zambia. To understand bureaucrat-politician linkages, as well as the implications of decentralization for service provision, insights were also gained from elected ward councilors, market committee members, and waste collection companies.

The findings reveal a number of needed changes in order to improve the decentralization process. First, a genuinely devolved system does allow local governments to hire and fire their staff. However, given that a relatively high degree of political interference was already reported by bureaucrats in such

\footnotetext{
${ }^{61}$ Department of Public Health, Southern Province.

${ }^{62}$ Department of public health, Copperbelt Province.

${ }^{63}$ Ward councilor, Lusaka.
} 
matters, the reinstatement of the LGSC seems justified for the medium-term. The LGSC claims and believes it adheres to a clear set of rules in its transfer decisions, but the implementation of these rules is interpreted as erratic and arbitrary by council bureaucrats and politicians. In particular, the transfers create uncertainty for bureaucrats, undermine institutional memory, and disrupt relationships with ward councilors, market committees, and private waste collectors. These findings also have been observed by the Parliamentary Committee on Local Governance (see GRZ 2017a).

A number of improvements seem valid. First, the LGSC should develop standardized tenure times for staff at different levels. Letters regarding transfers should be issued at a standard and sufficient period (for example, three months), before the tenure period is over so that bureaucrats can plan accordingly. If all local civil servants know that they cannot stay in a council past a certain time period, then the LGSC's concern that they will lobby to remain should not be a concern. In addition, there needs to be greater efficiency and transparency in deciding how staff are allocated to councils. Currently, the allocation of large numbers of unneeded staff in some councils hurts council budgets, overburdens already limited office space, and squeezes the resources available for service delivery. It seems illogical that councils need to pay for staff they did not request. Identifying whether councils have mis-budgeted for staff, whether the LGSC has not audited properly, or whether MLG approval for staff requests is so delayed that circumstances have changed by the time staff are transferred, is critical to determine who is accountable for this widespread problem and how to rectify it. Third, the establishment of an independent LGSC that is not solely appointed by the president could alleviate concerns, either valid or imagined, that the LGSC is sometimes used as a political tool. In addition, given that local bureaucrats are paid relatively little and irregularly compared with their central government counterparts and increasingly required to pursue higher levels of education, staff transfers that attempt to minimize the distance of bureaucrats from their families would be a costless incentive to attract a qualified workforce.

Second, the MLG needs to transition from a top-down to a partnership model of engagement with the councils. A policy document could be formulated to guide mutual institutional relations between local authorities and MLG that enshrines principles of cooperative governance in which top-down (MLG) and bottom up (local authorities) mutually relate on local development issues. In addition, a systematic approach is needed that allows for MLG to better communicate progress (or the lack thereof) on certain initiatives to the councils and for the councils to share issues of concern with the MLG. In addition, it may require allowing the councils greater flexibility in determining how national SIs are implemented in policy domains relevant to councils' exclusive responsibilities.

Third, the impacts of council proliferation in the country on service provision and citizen participation should be analyzed before more are created. The surveys and interviews from this study suggest that new councils create pressure on the LGSC to move staff around more frequently and result in 
poorly resourced councils that lack the capacity to fulfill the ambitious goals of the R-NDP. In theory, creating new council offices increases access of local citizens to the government; in practice, bureaucrats are working in substandard conditions and with a small local revenue base, which are not ideal conditions for improved service provision. Council proliferation also creates pressure on public financial management as the government tries to maintain enough inter-governmental transfers through the LGEF and the CDF to the growing number of disproportionately rural and poor councils. ${ }^{64}$

Citizen oversight and tracking of how council proliferation is affecting service provision would be a useful tool. Ghana, which began pursuing devolution in 2012 but continues to increase its number of Metropolitan, Municipal, and District Assemblies (MMDAs), can provide some useful lessons (see Resnick 2018). Specifically, Ghanaian civil society promoted the creation of District Lead Table, which ranks MMDAs according to their performance on education, sanitation, health, security, water, birth registration, and governance. ${ }^{65}$ The latter is captured by metrics on management of district fiscal capacity, planning, budgeting, and transparency, which all proxy for local government capacity. The rankings are publicly available every year, providing citizens a chance to see how their district fares on services for which local government is designated responsible and offers a way of keeping officials accountable. It also has the potential to increase competition among districts to better perform so that they are publicly recognized and not shamed ${ }^{66}$ In Zambia, such a tool could accompany efforts such as WDCs in order to help citizens gain valuable information about the areas where their councils are performing well and where more efforts are need. Since such efforts can help provide a repository on cross-sectoral local government performance for the central government, it can offer a way of measuring how devolution over time is affecting service delivery and where course corrections are needed. In addition, since improvement on the metrics requires cooperation between both administrative and political wings of local government, it could create a mechanism for aligning incentives between Zambian bureaucrats and ward councilors.

Fourth, in line with the R-NDP and the Seventh National Development Plan, the study confirmed that newer functions continue to be devolved to the councils, including education, health, and agricultural extension. According to the Cabinet Office Circular No.10 of 2014, financial resources earmarked for devolved functions were to be transferred to council treasuries as of 2016 (GRZ 2014e) but, three years later, this still seems to be lacking. Fully integrating these functions into the councils will require

\footnotetext{
${ }^{64}$ Since 2011, the CDF per constituency has increased from K500,000 to K700,000 and now K1.6million (see GRZ 2019b).

${ }^{65}$ For the most recent version, see https://www.unicef.org/ghana/media/2131/file/2018-2019-The-District-LeagueTable-II.pdf.

${ }^{66}$ Rwanda uses a similar approach by tying mayors to performance contracts based on indicators agreed between line ministries and the mayor and in the respective district's five-year development plan, with public awards for the best performing mayors each year (see Chemouni 2014).
} 
addressing disparities in salaries between existing council staff and those from the newly devolved departments as well as more efforts to transition budgets from sectoral ministries to those of the councils to ensure a joint program of service provision.

The Ghanaian and Kenyan examples are instructive in this regard. In Ghana, composite budgeting was adopted by the MMDAs, which involves all sectors negotiating over the local budget and receiving their financing through the Ministry of Finance and locally generated revenues than from a line ministry. It can increase the likelihood of sectoral technocrats to begin viewing themselves as members of local government rather than as an outposted employee of a central line ministry (Resnick 2018).

In Kenya, devolution to 47 counties was inscribed in the country's 2010 Constitution and officially implemented in 2013. Counties though did not have adequate training for budgeting for the additional staff they were to receive, leading to salary arrears. Kenya established a Salaries and Remuneration Commission which regularly reviews the remuneration and benefits of all civil servants and advises both the national and county governments on the harmonization, equity and fairness of remuneration to ensure adequate skill retention in the public sector (World Bank 2014). The Commissioners are nominated for appointment from four national bodies (Parliamentary Service Commission, Judicial Service Commission, Senate on behalf of the county governments, and the Defense Council), as well as by an umbrella body representing trade unions, an umbrella body representing employers, a joint forum of professional bodies, the Cabinet Secretary responsible for finance, the Attorney-General, and one person who has experience in the management of human resources in the public service, nominated by the Cabinet Secretary responsible for public service. ${ }^{67}$ As the tension over salary differentials could continue as the devolution process unfolds in Zambia, there is an even greater imperative for the LGSC to manage the transfer process responsibly and for the requests and allocation of personnel to be better informed by accurate data on actual ---not just budgeted---council revenues.

In both these and many other countries, appropriate sequencing of decentralized functions is critical to its successful implementation (see Falleti 2012), especially since overwhelmed councils with too many functions but too few resources can be accused of lacking capacity, creating a justification for recentralization down the line. Given these observations, it would seem prudent to complete the first of the three planned phases of devolution and learn relevant lessons before scaling up the process.

Overall, the 2019 Local Government Act is an important step towards trying to reconcile the many local government legislations that have emerged since the early 1990s. Based on the fieldwork for this study, however, much more effort is still needed on the ground, especially in identifying and tackling key political economy bottlenecks. Despite the onset of sectoral devolution in some service areas and the

\footnotetext{
${ }^{67}$ See https://www.src.go.ke/about-us/mandate-functions
} 
proliferation of councils, there are other legally mandated areas where council responsibilities are restrained or even being slowly retrenched. Specifically, the introduction of market boards and a solid waste agency may potentially improve service delivery in these two domains, but they will diminish the longstanding functional role that councils have played in these policy domains and suggest efforts at recentralization. Similarly, the recently proposed 2019 Constitution of Zambia (Amendment) Bill reverses the direct election of mayors by voters and reverts back to councilors selecting mayors (GRZ 2019d). This would undermine efforts to enhance accountability linkages between citizens and mayors that had been celebrated in the 2016 Constitution. Credibility about genuine intentions to deepen decentralization ultimately is signified by policy consistency and requires that such reforms can, if thoughtfully implemented, enhance development outcomes rather than only advance political goals. 


\section{References}

Andrews, Matt, Lant Pritchett, and Michael Woolcock. 2013. "Escaping Capability Traps through Problem Driven Iterative Adaptation (PDIA),"World Development. Vol.51: 234-244.

Ayee, Joseph. 2013. "Public administrators under democratic governance in Ghana." International Journal of Public Administration, Vol.36(6): 440-452.

Batley, Richard and Claire Mcloughlin. 2015. "The Politics of Public Services: A Service Characteristics Approach.” World Development, Vol.74: 275-285.

Brehm, J. and S. Gates. 1999. Working, shirking, and sabotage: Bureaucratic response to a democratic public. Michigan: University of Michigan Press.

Brierley, Sarah. Forthcoming. "Unprincipled Principals: Co-opted Bureaucrats and Corruption in Ghana." American Journal of Political Science.

Brinkerhoff, Derek and Omar Azfar. 2010. "Decentralization and community empowerment," in Ed Connerly, Kent Eaton, and Paul Smoke (eds). Making decentralization work: Democracy, Development, and Security. Boulder, CO: Lynne Rienner Publishers.

Callen, Michael, Saad Gulzar, Syed Ali Hasanain, and Yasir Khan. 2018. "The Political Economy of Public Sector Absence: Experimental Evidence from Pakistan.” NBER Working Paper Series No. 22340. Cambridge, MA: Harvard University.

Connerly, E., Kent Eaton, and Paul Smoke (eds.). 2010. Making Decentralization Work: Democracy, Development, and Security. Boulder, CO: Lynne Rienner Publishers.

Chemouni, Benjamin. 2014. "Explaining the design of the Rwandan decentralization: elite vulnerability and the territorial repartition of power." Journal of East African Studies, Vol.8(2): 246-262.

Chulu, Jimmy. 2014. "Local Government Financing Framework: A Perspective Review of Zambian Local Governments." Journal of Local Government Studies. Vol.1(4).

Dasandi, Nioheer and Marc Esteve. 2017. "The Politics-Bureaucracy Interface in Developing Countries." Public Administration and Development, Vol.37: 231-245.

Eaton, Kent, Kai Kaiser, and Paul Smoke. 2011. The Political Economy of Decentralization Reforms in Developing Countries: Implications for Aid Effectiveness. Washington, DC: World Bank.

Ejersbo, Niels and James Svara. 2012. "Bureaucracy and Democracy in Local Government," in Peter John, Karen Mossberger, and Susan Clarke (eds.), The Oxford Handbook of Urban Politics. Oxford, UK: Oxford University Press.

Ellermann, Antje. 2005. "Coercive Capacity and the Politics of Implementation: Deportation in Germany and the United States." Comparative Political Studies, Vol.38(10): 1219-1244.

Estache, Antonio, Grégoire Garsous, and Ronaldo Seroa da Motta. 2016. "Shared Mandates, Moral Hazard, and Political (Mis)alignment in a Decentralized Economy." World Development, Vol.83: 98-110.

Faguet, J.P. 2014. “Decentralisation and governance.” World Development, Vol.53(1): 2-13. 
Falleti, Tulia. 2012. Decentralization and subnational Politics in Latin America. New York: Cambridge University Press.

Ferraz, C. and F. Finan. 2011. "Electoral Accountability and Corruption: Evidence from the Audit Reports of Local Governments.” American Economic Review, Vol.101: 1274-1311.

Finan, F., B. Olken, and R. Pande. 2017. "The Personnel Economics of the Developing State," chapter 6 of the Handbook of Field Experiments Volume II. Amsterdam: North Holland.

Fukuyama, Francis. 2013. "What is governance?” Governance, Vol.26(3): 347-368.

Gibson, Edward. 2013. Boundary Control: Subnational Authoritarianism in Federal Democracies. New York: Cambridge University Press.

Gonzalez-Ocantos, Ezequiel, Chad Kiewiet De Jonge, Carlos Meléndez, Javier Osorio and David W Nickerson. 2012. "Vote buying and social desirability bias: Experimental evidence from Nicaragua." American Journal of Political Science, Vol. 56(1):202-217.

Government of the Republic of Zambia (GRZ). 1991. The Local Government Act. Lusaka, Zambia: Ministry of Legal Affairs.

Government of the Republic of Zambia (GRZ). 2002. The National Decentralisation Policy: "Towards Empowering the People." Lusaka, Zambia: Office of the President, Cabinet Office.

Government of the Republic of Zambia (GRZ). 2009. Decentralization Implementation Plan, 20092013. Lusaka, Zambia: Ministry of Local Government and Housing.

Government of the Republic of Zambia (GRZ). 2010. The Local Government (Amendment), No.6 of 2010. Lusaka, Zambia: National Assembly.

Government of the Republic of Zambia (GRZ). 2013. Report of the Committee on Local Governance, Housing, and Chiefs' Affairs for the Third Session of the Eleventh National Assembly Appointed on $25^{\text {th }}$ September. Lusaka, Zambia: National Assembly.

Government of the Republic of Zambia (GRZ). 2014a. The Local Government (Amendment). Lusaka, Zambia: Attorney-General.

Government of the Republic of Zambia (GRZ). 2014b. National Planning and Budgeting Policy: Responsive, Transparent, Accountable and Results-Oriented Development Planning and Budgeting Processes. Lusaka, Zambia: Ministry of Finance.

Government of the Republic of Zambia (GRZ). 2014c. Decentralisation Implementation Plan (DIP), 2014-2017. Lusaka, Zambia: Decentralisation Secretariat.

Government of the Republic of Zambia (GRZ). 2014d. Summary of the Organisation Structures for City, Municipal, and District councils in accordance with the National Decentralisation Policy. Lusaka, Zambia: Ministry of Local Government and Housing.

Government of the Republic of Zambia (GRZ). 2014e. Cabinet Office Circular Number 10 of 2014. Lusaka, Zambia: Office of the President.

Government of the Republic of Zambia (GRZ). 2015. Zambia Labor Force Survey Report, 2014. Lusaka, Zambia: Central Statistical Office. 
Government of the Republic of Zambia (GRZ). 2017a. Report on the Committee on Local Governance, Housing, and Chiefs' Affairs for the Second Session of the Twelfth National Assembly Appointed on Thursday, 21 September. Lusaka, Zambia: National Assembly.

Government of the Republic of Zambia (GRZ). 2017b. Ministerial Statement by the Hon. Minister of Local Government Hon. Vincent Mwale, MP, on Upgrading of Councils and Establishment of New Councils, 3 March. Lusaka, Zambia: National Assembly.

Government of the Republic of Zambia (GRZ). 2018a. 2017 Decentralisation Annual Report. Lusaka, Zambia: Decentralisation Secretariat.

Government of the Republic of Zambia (GRZ). 2018b. Report of the Auditor General on the Review of Operations of Local Authorities for the Financial Years ended $21^{\text {st }}$ December 2014, 2015, 2016. Lusaka, Zambia: Office of the Auditor General.

Government of the Republic of Zambia (GRZ). 2018c. Ministerial Statement by the Hon. Minister of Local Government Hon. Vincent Mwale, MP, Appointment of Market and Bus Station Boards and the Provision of Alternative Trading Land for Street Traders. 20 March. Lusaka: National Assembly.

Government of the Republic of Zambia (GRZ). 2019a. The Local Government Act, No.2 of 2019. Lusaka, Zambia: Attorney General.

Government of the Republic of Zambia (GRZ). 2019b. Parliamentary Hansard, 18 June. Lusaka, Zambia: National Assembly. Available at: http://www.parliament.gov.zm/node/7989

Government of the Republic of Zambia (GRZ). 2019d.

Grindle, Merilee. 1997. "Divergent cultures? When public organizations perform well in developing countries." World Development, Vol.25(4): 481-495.

Hampwaye, Godfrey. 2008. "The Limits of Decetnralisation in Urban Zambia.” Urban Forum, Vol.19: 347-361.

Iyer, Lakshimi and Anandi Mani. 2012. "Traveling Agents: Political Change and Bureaucratic Turnover in India." The Review of Economics and Statistics, Vol. 94(3):723-739.

International Monetary Fund (IMF). 2019. Zambia Technical Assistance Report - Government Finance Statistics Mission. IMF Country Report No. 19/78. Washington, DC: IMF.

Jackson, S.E. 1995. "Consequences of diversity in multidisciplinary work teams," in M.A.West (ed.), Handbook of work group psychology. Chichester, England: Wiley: 53-75.

Janis, I.L. 1982. Victims of groupthink. Boston: Houghton Mifflin.

Kaza, Silpa, Lisa Yao, Perinaz Bhada-Tata, and Frank Van Woerden. 2018. What a Waste 2.0: A Global Snapshot of Solid Waste Management to 2050. Washington, DC.

Keefer, Phil and Stuti Khemani. 2009. "When do Legislators Pass on Pork? The Role of Political Parties in Determining Legislator Effort." The American Political Science Review, Vol.81: 929-945.

Lederman, Daniel, Norman V. Loayza, and Rodrigo R. Soares. 2005. “Accountability and Corruption: Political Institutions Matter.” Economics and Politics, Vol.17(1): 1-35. 
Local Government Association of Zambia (LGAZ). 2014. 50 Years of Local Government in Zambia: Treasuring the Past, Reflecting the Present, Shaping the Future. Lusaka, Zambia: LGAZ.

Lusaka Times. 2018a. "President Edgar Lungu has declared 7 new districts," 11 April. Available at https://www.lusakatimes.com/2018/04/11/president-edgar-lungu-has-declared-7-new-districts/ (Access May 23, 2019).

Lusaka Times. 2018b. "President Lungu to soon employ District commissioners in all the 5 newly created districts." 22 July. Available at https://www.lusakatimes.com/2018/07/22/president-lungu-tosoon-employ-district-commissioners-in-all-the-5-newly-created-districts/ (Accessed February 22, 2019).

Lusaka Times.2018c. "Government approves Solid Waste Regulation and Management Bill.” 16 November. Available at https://www.lusakatimes.com/2018/11/16/government-approves-solidwaste-regulation-and-management-bill/ (Accessed July 11, 2019).

Lusaka Times. 2019. "Police ordered to immediately stop confiscating products from street vendors." 6 July. Available at https://www.lusakatimes.com/2019/07/06/police-ordered-to-immediately-stopconfiscating-products-from-street-vendors/ (Accessed July 22, 2019).

Malesky, Edmund J, Dimitar D Gueorguiev and Nathan M Jensen. 2015. "Monopoly money: Foreign investment and bribery in Vietnam, a survey experiment." American Journal of Political Science, Vol. 59(2):419-439.

Mwasile, Fred. 2014. "Human Resource Development and Management in Local Government in Zambia," chapter 4 in 50 Years of Local Government in Zambia: Treasuring the Past, Reflecting the Present, Shaping the Future. Lusaka, Zambia: Local Government Association of Zambia.

Muller, Luke, Eric Ciaraldi, Andrew McNaught, Jonathan Allaire, and Andrew Ngwenya. 2017. Waste as a Resource: Development Opportunities within Zambia's Waste Value Chain and Management System. International Labor Organization.

Oates, William. 1985. "Searing for Leviathan: An Empirical Study," American Economic Review. Vol.75:748-757.

Oates, William. 1972. Fiscal Federalism. New York: Harcourt Brace Jovanovich.

Pires, R.R.C. 2011. "Beyond the fear of discretion: Flexibility, performance, and accountability in the management of regulatory bureaucracies," Regulation and Governance. Vol.5(1): 43-69.

Ponce-Rodríguez, Raul, Charles Hankla, Jorge Martinez-Vazquez, and Eunice Heredia-Ortiz. 2018. "Rethinking the Political Economy of Decentralization: How Elections and Parties Shape the Provision of Local Public Goods." Publius: The Journal of Federalism. Vol.48(4): 523-558.

Resnick, Danielle. 2014. "Strategies of Subversion in Vertically-Divided Contexts: Decentralisation and Urban Service Delivery in Senegal.” Development Policy Review, Vol.32(s1): s61-s80.

Resnick, Danielle. 2018. "Devolution Revolution: Implications for agricultural service delivery in Ghana." IFPRI Discussion Paper No. 1714. Washington, DC: International Food Policy Research Institute.

Rogger, Daniel. 2018. "The Consequences of Political Interference in Bureaucratic Decision Making: Evidence from Nigeria.” Policy Research Working Paper No.8554. Washington, DC: World Bank. 
Smoke, Paul. 2015. "Rethinking Decentralization: Assessing Challenges to a Popular Public Sector Reform." Public Administration and Development, Vol.35: 97-112.

Tiebout, Charles. 1956. “A Pure Theory of Local Expenditures.” Journal of Political Economy, Vol.64(5): 416-424.

Tordoff, William and Ralph Young. 1994. "Decentralisation and Public Sector Reform in Zambia." Journal of Southern African Studies. Vol.20(2): 285-299.

Tummers, Lars and Victor Bekkers. 2014. "Policy Implementation, Street-level Bureaucracy, and the Importance of Discretion." Public Management Review, Vol.16(4): 527-547.

Wallace, J.J. and Oates, W.E. 1988. "Decentralisation in the Public Sector: An Empirical Study of State and Local Government," in H.S. Rosen (ed) Fiscal Federalism: Quantitative Studies, (Chicago: University of Chicago Press)

Weingast, Barry. 2014. "Second Generation Fiscal Federalism: Political Aspects of Decentralization and Economic Development." World Development, Vol.53: 14-25.

Wilson, James Q. 1989. Bureaucracy: What Government Agencies Do and Why they Do It. New York: Basic Books.

World Bank. 2015. Mapping Subnational Poverty in Zambia. Washington, DC: World Bank.

World Bank. 2014. The Evolution of Kenya's Devolution: What's working well, what could work better. Washington, DC: World Bank.

Zambian Observer. 2017. "Livingstone councilors plan to petition Lungu over huge council transfers," 25 December. Available at https://www.zambianobserver.com/livingstone-councilors-plan-topetition-lungu-over-huge-council-transfers/ (Access on March 19, 2019).

Zande, Steven. 2019. "Cities to lose grants." Times of Zambia. Available at: http://www.times.co.zm/?p=106287 (Accessed May 23, 2019). 


\section{Appendices}

Table A.1: Diversity in schools

\begin{tabular}{|l|c|c|c|c|}
\hline & Director & Mid-level & Lower level & Total \\
\hline Cavendish University & 2.5 & 5.7 & 0.0 & 3.3 \\
\hline Copperbelt University & 15.0 & 14.3 & 7.0 & 12.4 \\
\hline Copperstone University & 7.5 & 2.9 & 2.3 & 3.9 \\
\hline Evelyn Hone College & 0.0 & 2.9 & 9.3 & 3.9 \\
\hline Local Government Training Institute & 0.0 & 0.0 & 9.3 & 2.6 \\
\hline Mulungushi University & 7.5 & 2.9 & 7.0 & 5.2 \\
\hline National Institute of Public Administration & 5.0 & 2.9 & 13.9 & 6.5 \\
\hline Rusangu University & 2.5 & 7.1 & 4.7 & 5.2 \\
\hline University of Zambia & 15.0 & 30.0 & 16.3 & 22.2 \\
\hline University of Lusaka & 15.0 & 4.3 & 0.0 & 5.9 \\
\hline Zambia Institute of Chartered Accountants & 0.0 & 7.1 & 7.0 & 5.2 \\
\hline Zambia Centre for Accountancy Studies & 2.5 & 2.9 & 0.0 & 2.0 \\
\hline Zambia Open University & 0.0 & 2.9 & 2.3 & 2.0 \\
\hline University outside of Zambia & 20.0 & 7.1 & 7.0 & 10.5 \\
\hline Other University in Zambia & 7.5 & 7.1 & 13.9 & 9.2 \\
\hline N & 40 & 70 & 43 & 153 \\
\hline
\end{tabular}

Source: IFPRI-UNZA Zambia Local Bureaucrats survey.

Notes: 'Other' category includes Chainama College of Health Sciences, Chreso University, Saint Eugene

University, University of Africa, Zambia Catholic University, Zambia Insurance Business College Trust, Zambia

College of the Built Environment

Table A.2: Balance Table for List Experiment

\begin{tabular}{|c|c|c|c|c|}
\hline Variables & Control & Treatment & Difference & P-Value \\
\hline \multicolumn{5}{|c|}{ Individual Level } \\
\hline Female & 0.45 & 0.36 & 0.09 & 0.257 \\
\hline Masters & 0.12 & 0.13 & -0.01 & 0.895 \\
\hline $\begin{array}{l}\text { Years in } \\
\text { government }\end{array}$ & 9.10 & 9.33 & -0.23 & 0.870 \\
\hline \multicolumn{5}{|l|}{ Council Level } \\
\hline PF mayor & 0.66 & 0.61 & 0.05 & 0.537 \\
\hline Town council & 0.34 & 0.35 & -0.01 & 0.912 \\
\hline City council & 0.21 & 0.24 & -0.03 & 0.670 \\
\hline
\end{tabular}

Notes: Control $=68$ and Treatment $=72$ 


\section{ALL IFPRI DISCUSSION PAPERS}

All discussion papers are available here

They can be downloaded free of charge

INTERNATIONAL FOOD POLICY RESEARCH INSTITUTE

www.ifpri.org

\section{IFPRI HEADQUARTERS}

1201 Eye Street, NW

Washington, DC 20005 USA

Tel.: +1-202-862-5600

Fax: +1-202-862-5606

Email: ifpri@cgiar.org 